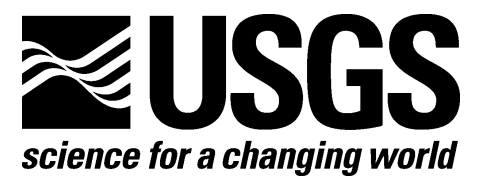

Prepared in cooperation with the Bureau of Land Management

\title{
Review of Samples of Water, Sediment, Tailings, and Biota at the Little Bonanza Mercury Mine, San Luis Obispo County, California
}

By James J. Rytuba, Roger L. Hothem, Daniel N. Goldstein, Brianne E. Brussee, and Jason T. May

Open-File Report 2011-1122

U.S. Department of the Interior

U.S. Geological Survey 


\section{U.S. Department of the Interior KEN SALAZAR, Secretary}

\section{U.S. Geological Survey \\ Marcia K. McNutt, Director}

U.S. Geological Survey, Reston, Virginia 2010

For more information on the USGS—-the Federal source for science about the Earth, its natural and living resources, natural hazards, and the environment:

World Wide Web: http://www.usgs.gov

Telephone: 1-888-ASK-USGS

Suggested citation:

Rytuba, J.J., Hothem, R.L., Goldstein, D.N., Brussee, B.E., and May, J.T., 2011, Review of samples of water, sediment, tailings, and biota at the Little Bonanza mercury mine, San Luis Obispo County, California: U.S. Geological Survey Open-File Report 2011-1122, 46 p. [http://pubs.usgs.gov/of/2011/1122/].

Any use of trade, product, or firm names is for descriptive purposes only and does not imply endorsement by the U.S. Government.

Although this report is in the public domain, permission must be secured from the individual copyright owners to reproduce any copyrighted material contained within this report. 


\section{Contents}

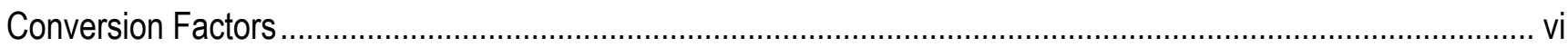

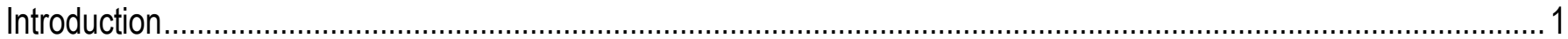

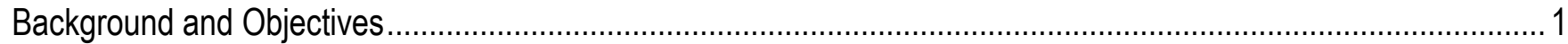

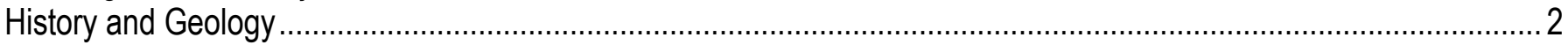

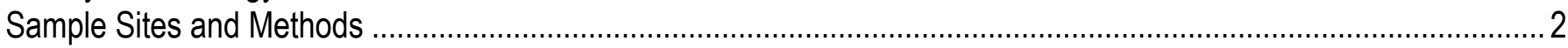

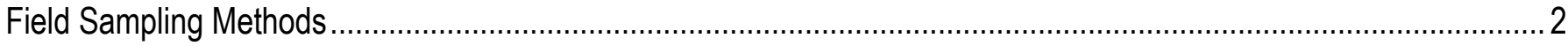

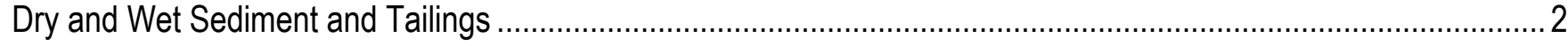

Water

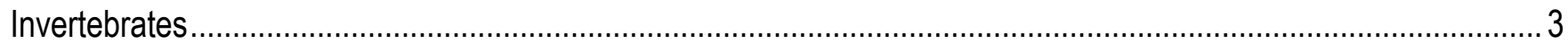

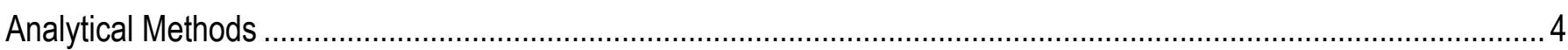

Sediments and Tailings …………………………

Water

Biota

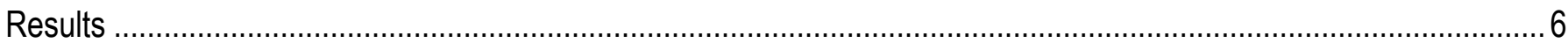

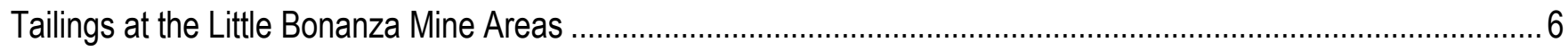

Sediment in WF Las Tablas Creek near the Little Bonanza Mine ……….......................................................

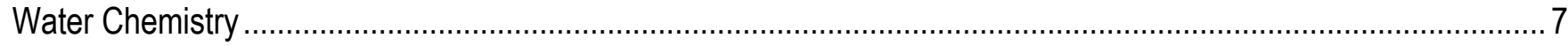

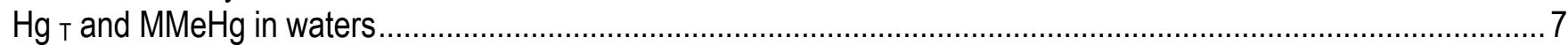

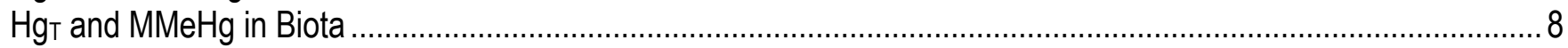

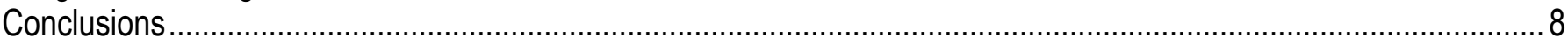

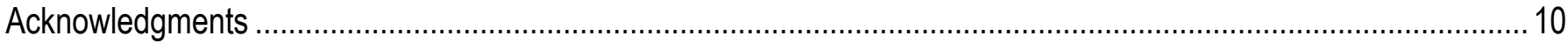

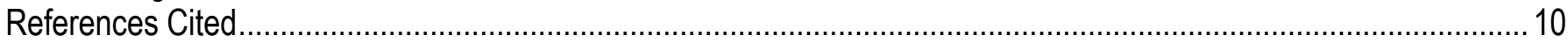

\section{Tables}

Table 1. Sample locations and physical and selected chemical parameters for waters from the Little Bonanza Mine on April 6, 2010.

Table 2. Mercury and associated major and minor elements in sediment, precipitates, and calcines from the Little

Bonanza Mine.

Table 3. Mercury and monomethylmercury concentrations in waters and sediment.

Table 4. Geochemistry of filtered samples from the Little Bonanza Mine, ICP-MS results (major elements, ICP-AES

results)

Table 5. Geochemistry of unfiltered samples from the Little Bonanza Mine, ICP-MS results (major elements, ICP-

AES results). 
Table 6. Invertebrate samples collected from the Little Bonanza Mine and Trout Creek on April 6, 2010.

Table 7. Sample sites and physical and selected chemical parameters for waters from the Little Bonanza Mine collected during a high-flow sampling event.

Table 8. Mercury and monomethylmercury concentrations in waters and sediment collected during a high-flow sampling event

Table 9. Concentrations of anions and selected cations in filtered water from the Little Bonanza Mine collected during a high-flow sampling event.

Table 10. Geochemistry of filtered samples from the Little Bonanza Mine collected during a high-flow sampling event, ICP-MS results (major elements, ICP-AES results)

Table 11. Geochemistry of unfiltered samples from the Little Bonanza Mine collected during a high-flow sampling event, ICP-MS results (major elements, ICP-AES results)

\section{Figures}

Figure 1. General geology of the Little Bonanza Mine area (Yates and others, 1941). The workings at Little Bonanza explore a zone of fault breccia that trends northwest. The breccia consists of fragments of sandstone, greenstone, serpentine, and chert in a shale matrix.

Figure 2. Vertical projection of workings at the Little Bonanza Mine (Yates and others, 1941).............................29

Figure 3. Cross-section of ore shoots at the Little Bonanza Mine (Yates and others, 1941). 30

Figure 4. Mine workings at the Little Bonanza Mine, with a cross section showing alteration and mercury ore zones

(Yates and others, 1941). 31

Figure 5. Three-pipe retort at the Little Bonanza Mine that was used to process $\mathrm{Hg}$ ores. 32

Figure 6. Mine processing area at the Little Bonanza Mine, showing remains of a three-pipe retort. 33

Figure 7. Calcines (mine tailings) adjacent to retort at the Little Bonanza Mine. 34 
Figure 8. Sulfides that formed in three-pipe retort at the Little Bonanza Mine. 35

Figure 9. Calcines (mine tailings) at the Little Bonanza Mine exposed along bank of WF Las Tablas Creek. 36

Figure 10. Little Bonanza Mine area, showing locations of all sample sites (Google Earth). Area in yellow box is shown in detail in figure 11

Figure 11. Closeup of figure 10, showing locations of sample sites in mine area (Google Earth). Yellow box delineates land managed by BLM.

Figure 12. Coarse-grained calcines (mine tailings) exposed in bank of WF Las Tablas Creek at the Little Bonanza Mine. 39

Figure 13. Sample site 10LB1 in WF Las Tablas Creek at the Little Bonanza Mine. 40

Figure 14. Sample site 10LB3 in creek that extends into area of dam, now failed, at the Little Bonanza Mine 41

Figure 15. Hg concentration in unfiltered versus filtered samples from the Rinconada and Little Bonanza Mines...42 Figure 16. Hg versus MMeHg concentrations in unfiltered water samples from the Rinconada and Little Bonanza

Mines 43

Figure 17. $\mathrm{Hg}$ concentration versus \%MMeHg in sediment samples from the Little Bonanza Mine. 44

Figure 18. MMeHg concentration versus \%MMeHg in sediment samples from the Little Bonanza Mine. 45

Figure 19. Comparison of $\mathrm{Hg}_{\mathrm{T}}$ and dissolved $\mathrm{Hg}$ concentrations in waters sampled at the Little Bonanza Mine, beginning with the most upstream sample site, LB2, at the adit, and moving downstream to sample sites LB1, LB3,

LB4 and LB5, respectively. 


\section{Abbreviations, Definitions, Datum Used, and Conversion Factors}

Vertical and horizontal coordinate information is referenced to the North American Datum of 1927

DOC, dissolved organic carbon

DOM, dissolved organic matter

EE/CA, engineering evaluation/cost analysis for "non-time-critical removal actions," as defined by the U.S. Environmental Protection Agency's Comprehensive Environmental Response, Compensation, and Liability Act (CERCLA).

$\mathrm{Hg}$, elemental symbol for mercury; does not denote speciation.

$\mathrm{Hg}_{\mathrm{T}}$, total mercury (inorganic plus organic).

$\mathrm{Hg}_{\mathrm{F}}$, total mercury (inorganic plus organic) in a filtered sample (either 0.1 or $0.45 \mu \mathrm{m}$, as specified in the text).

$\mathrm{MMeHg}$, monomethylmercury, methylmercury, and monomethylmercury ion $\left(\mathrm{CH}_{3} \mathrm{Hg}^{+}\right)$

$\mathrm{ng} / \mathrm{g}$, nanogram per gram, equivalent to parts per trillion.

$\mathrm{ng} / \mathrm{L}$, nanogram per liter, approximately equivalent to parts per trillion.

$\mathrm{ppm}$, parts per million, equivalent to $\mathrm{mg} / \mathrm{kg}$ or $\mu \mathrm{g} / \mathrm{g}$.

SC, specific (electrical) conductivity, reported in units of millisiemens per centimeter $(\mathrm{mS} / \mathrm{cm})$.

Flask, $34.5 \mathrm{~kg}$ or $76 \mathrm{lb}$ of $\mathrm{Hg}$

$\mathrm{RPD}$, relative percent difference

ANOVA, analysis of variance

ASTM, American Society for Testing and Materials

BLM, Bureau of Land Management

CDFG, California Department of Fish and Game

$\mathrm{Cl}$, chloride

CVAFS, cold-vapor atomic-fluorescence spectroscopy

CVAAS, cold-vapor atomic-absorbption spectroscopy

CVRWQCB, Central Valley Regional Water Quality Control Board

$\mathrm{HCl}$, hydrochloric acid

$\mathrm{H}_{2} \mathrm{SO}_{4}$, sulfuric acid

ICP-AES, inductively-coupled plasma atomic-emission spectroscopy

ICP-MS, inductively-coupled plasma-mass spectroscopy

TMDL, total maximum daily load

EPA, U.S. Environmental Protection Agency

USGS, U.S. Geological Survey

Conversion Factors

\begin{tabular}{lcl}
\hline & Multiply & \multicolumn{1}{c}{ Bo obtain } \\
\hline inch (in.) & Length & \\
inch (in.) & 2.54 & centimeter (cm) \\
foot (ft) & 25.4 & millimeter (mm) \\
mile (mi) & 0.3048 & meter (m) \\
\hline & 1.609 & kilometer (km) \\
\hline acre & Area & \\
acre & 4,047 & square meter $\left(\mathrm{m}^{2}\right)$ \\
acre & 0.4047 & hectare (ha) \\
\hline & 0.004047 & square kilometer $\left(\mathrm{km}^{2}\right)$ \\
\hline gallon (gal) & Volume & \\
& 3.785 & liter (L)
\end{tabular}




\begin{tabular}{lll} 
gallon $(\mathrm{gal})$ & 0.003785 & cubic meter $\left(\mathrm{m}^{3}\right)$ \\
cubic inch $\left(\mathrm{in}^{3}\right)$ & 16.39 & cubic centimeter $\left(\mathrm{cm}^{3}\right)$ \\
cubic inch $\left(\mathrm{in}^{3}\right)$ & 0.01639 & liter $(\mathrm{L})$ \\
cubic foot $\left(\mathrm{ft}^{3}\right)$ & 0.02832 & cubic meter $\left(\mathrm{m}^{3}\right)$ \\
\hline & Flow rate & \\
\hline cubic foot per second $\left(\mathrm{ft}^{3} / \mathrm{s}\right)$ & 0.02832 & cubic meter per second $\left(\mathrm{m}^{3} / \mathrm{s}\right)$ \\
gallon per minute $(\mathrm{gal} / \mathrm{min})$ & 0.06309 & liter per second $(\mathrm{L} / \mathrm{s})$ \\
\hline & Mass & \\
\hline gram $(\mathrm{g})$ & 0.03527 & ounce, avoirdupois $(\mathrm{oz})$ \\
\hline kilogram & 2.205 & pound, avoirdupois $(\mathrm{lb})$ \\
\hline microgram $(\mu \mathrm{g})$ & 0.0000000353 & ounce, avoirdupois $(\mathrm{oz})$ \\
\hline milligram $(\mathrm{mg})$ & 0.0000353 & ounce, avoirdupois $(\mathrm{oz})$ \\
\hline nanogram $(\mathrm{ng})$ & 0.0000000000353 & ounce, avoirdupois $(\mathrm{oz})$ \\
\hline ounce, avoirdupois $(\mathrm{oz})$ & 28.35 & gram $(\mathrm{g})$ \\
pound, avoirdupois $(\mathrm{lb})$ & 0.4536 & kilogram $(\mathrm{kg})$ \\
\hline
\end{tabular}

Temperature in degrees Celsius $\left({ }^{\circ} \mathrm{C}\right)$ may be converted to degrees Fahrenheit $\left({ }^{\circ} \mathrm{F}\right)$ as follows:

${ }^{\circ} \mathrm{F}=\left(1.8 \times{ }^{\circ} \mathrm{C}\right)+32$

Temperature in degrees Fahrenheit $\left({ }^{\circ} \mathrm{F}\right)$ may be converted to degrees Celsius $\left({ }^{\circ} \mathrm{C}\right)$ as follows:

${ }^{\circ} \mathrm{C}=\left({ }^{\circ} \mathrm{F}-32\right) / 1.8$

Specific conductance is given in microsiemens per centimeter $(\mu \mathrm{S} / \mathrm{cm})$ at $25^{\circ} \mathrm{C}$

Concentrations of chemical constituents in water are given in milligrams per liter (mg/L, parts per million), micrograms per liter ( $\mu \mathrm{g} / \mathrm{L}$, parts per billion), or nanograms per liter (ng/L, parts per trillion).

Concentrations of chemical constituents in tissues are given in micrograms per gram ( $\mu \mathrm{g} / \mathrm{g}$, parts per million).

Concentrations of chemical constituents in sediment are given in micrograms per gram ( $\mu \mathrm{g} / \mathrm{g}$, parts per million) or nanograms per gram (ng/g, parts per billion) 


\section{Review of Samples of Water, Sediment, Tailings, and Biota at the Little Bonanza Mercury Mine, San Luis Obispo County, California}

By James J. Rytuba, ${ }^{1}$ Roger L. Hothem, ${ }^{2}$ Daniel N. Goldstein, ${ }^{1}$ Brianne E. Brussee, ${ }^{2}$ and Jason T. May ${ }^{3}$

\section{Introduction}

\section{Background and Objectives}

The Little Bonanza mercury $(\mathrm{Hg})$ mine, located in San Luis Obispo County, California, is a relatively small mine with a historical total $\mathrm{Hg}$ production of about 1,000 flasks (fig. 1). The mine workings and tailings are located in the headwaters of the previously unnamed west fork of Las Tablas Creek (WF Las Tablas Creek), which flows into the Nacimiento Reservoir. Wasterock and tailings eroded from the Little Bonanza $\mathrm{Hg}$ Mine have contributed $\mathrm{Hg}$-enriched mine wastes to the headwaters of WF Las Tablas Creek. The mine is located on Federal land managed by the U.S. Bureau of Land Management (BLM), which requested that the U.S. Geological Survey (USGS) measure and characterize $\mathrm{Hg}$ and other geochemical constituents in tailings, sediment, water, and biota at and downstream from the minesite. This report is in response that request, from the lead agency which is mandated to conduct a Comprehensive Environmental Response, Compensation, and Liability Act (CERCLA) - Removal Site Investigation (RSI). The RSI applies to removal of Hg-contaminated mine waste from the Little Bonanza minesite as a means of reducing $\mathrm{Hg}$ transport to WF Las Tablas Creek.

\footnotetext{
${ }^{1}$ U.S. Geological Survey, Menlo Park, California.

${ }^{2}$ U.S. Geological Survey, Dixon, California

${ }^{3}$ U.S. Geological Survey, Sacramento, California
} 
This report summarizes data obtained from field sampling of mine tailings, wasterock, sediment, water, and biota at the Little Bonanza Mine that was completed on April 6, 2010. Conditions during sampling were dry and no rain had occurred in the watershed for several weeks. Our results permit a preliminary assessment of the mining sources of $\mathrm{Hg}$ and associated chemical constituents that could produce elevated levels of monomethyl mercury (MMeHg) in WF Las Tablas Creek and in biota.

\section{History and Geology}

The history of the Little Bonanza Hg mine is summarized here from Yates (1943) and other references as cited. The Little Bonanza Mine, located $20 \mathrm{mi}$ west of Paso Robles, was discovered in 1862. Although production was minor until 1900, from 1900 to 1906, the mine produced about 1,000 flasks of $\mathrm{Hg}$. Intermittent production continued into the 1940s but was relatively limited. Underground workings, now caved and inaccessible, include about 3,000 ft of drifts, crosscuts, and raises on three levels extending $260 \mathrm{ft}$ downward (figs. 1, 2).

The workings at the Little Bonanza Mine explore a zone of fault breccia, which trends northwest (fig. 1). The breccia is composed of fragments of sandstone, greenstone, serpentine, and chert in a shale matrix. The serpentine has been hydrothermally altered to silica-carbonate rock, and the Hg deposit is hosted within the zone of alteration. The veins are discontinuous and irregular, but form a steplike pattern along the fault zone (figs. 3, 4). The principal mineralization occurring in the veins is irregular, consisting of disseminated zones of cinnabar. Most of the veins in the mine area contain cinnabar.

\section{Sample Sites and Methods}

Samples were collected to assess the concentrations of $\mathrm{Hg}$ and biogeochemically relevant constituents in tailings and wasterock piles at the Little Bonanza Hg mine. Tailings are present adjacent to a three-pipe retort used to process the $\mathrm{Hg}$ ore (figs. 5, 6). The tailings occur in the upper $15 \mathrm{~cm}$ of the soil adjacent to the retort (fig. 7) and slag from the retort is present on the surface (fig. 8). An area of disturbed soil and rock uphill from the retort was likely formed during construction of a dam that provided water for mining activities. Wasterock in these piles was sampled (fig. 6). The largest amount of tailings is exposed to the west of the retort in the bank of WF Las Tablas Creek (fig. 9). Water, sediment, and biota were sampled from WF Las Tablas Creek, which flows through the mine area. Sample-site locations are shown in figures 10 and 11 and listed in table 1. Samples were collected when streamflow was low and no precipitation had occurred.

\section{Field Sampling Methods}

\section{Dry and Wet Sediment and Tailings}

Samples consisting of 100 to $500 \mathrm{~g}$ of mine tailings and wasterock were collected from piles at the Little Bonanza Hg mine, stored, and shipped in Ziploc ${ }^{\circledR}$ bags at ambient temperature. Wet sediment was collected in polycarbonate jars (100-mL capacity) and frozen with dry ice immediately after collection (freezing time, approx 20-30 minutes). Samples were kept frozen 
until shipped overnight on dry ice to the analytical laboratory (Brooks Rand, Seattle, WA), where they were kept frozen until analysis. The temperature of samples arriving at the laboratory ranged from $1^{\circ} \mathrm{C}$ to $4^{\circ} \mathrm{C}$, within the limits specified in USEPA method $1631 \mathrm{E}$.

\section{Water}

Stream and adit drainage samples were collected with new $60-\mathrm{mL}$ sterile polypropylene syringes. Bulk water samples were subsampled for analysis of metal(loid)s and anions. Subsamples for metal(loid) determinations were acidified to $\mathrm{pH}<2$ with trace metal (Ultrex, J.T. Baker)-grade $\mathrm{HNO}_{3}$ and stored in acid-washed, high-density polyethylene (HDPE) bottles. Subsamples for anion and alkalinity measurements were filtered, stored in HDPE bottles, and chilled to approximately $4^{\circ} \mathrm{C}$ until analysis, in accordance with USGS protocols for trace metals (http://pubs.water.usgs.gov/twri9A). Water samples were filtered with disposable 25-mmdiameter sterile cellulose acetate filters $(0.45-\mu \mathrm{m}$ openings $)$ in the field for analysis of anions and alkalinity, and for inductively coupled plasma mass spectrometry (ICP-MS) and inductively coupled plasma atomic-emission spectrometric (ICP-AES) analyses.

Water variables, including $\mathrm{pH}$, conductivity, and temperature, dissolved oxygen, and oxidation-reduction potential (ORP), were measured in the field, using a battery-powered Sonde hydrolab. Measurements were taken by placing the probe directly into the flowing streamwater.

Samples for total $\mathrm{Hg}\left(\mathrm{Hg}_{\mathrm{T}}\right)$ and $\mathrm{MMeHg}$ analyses were collected in trace-metal-free certified $250 \mathrm{~mL}$ bottles (Nalgene ICHEM) with no headspace. The MMeHg bottles contained an $\mathrm{HCl}$ preservative provided by the analytical laboratory. Procedures for $\mathrm{Hg}_{\mathrm{T}}$ analysis followed ultra clean sampling and handling protocols (Bloom, 1995, Gill and Fitzgerald, 1987) during the collection of field samples and subsequent analysis to avoid introduction of $\mathrm{Hg}$. Samples were kept on ice until shipped. Samples were shipped on icepacks and arrived the next morning at the analytical facilities at temperatures ranging from 1 to $4^{\circ} \mathrm{C}$, as specified by EPA method 1631E, to minimize biologically induced phase changes and $\mathrm{MMeHg}$ degradation.

During every sampling event, a field blank was collected by processing deionized water and collecting the same subsamples (except for alkalinity), following the same procedures as used for the field samples. Laboratory blanks and acid blanks were processed periodically to determine whether our equipment, containers, reagents, and procedures introduced significant contamination.

\section{Invertebrates}

The target macroinvertebrates for this study were predatory insects, depending on their abundance and availability at each sample site. Taxa collected were larval dragonflies (order Odonata, families Aeshnidae and Gomphidae), adult water striders (order Hemiptera, family Gerridae), predaceous diving beetles (order Coleoptera, family Dytiscidae), and larval dobsonflies (order Megaloptera, family Corydalidae).

Invertebrates were collected with dipnets and by hand and placed in Ziploc plastic bags with native water. Samples were kept in a cooler and allowed to depurate in native water on wet ice for 4-24 hours before being sorted at the end of the collection day. Individuals were sorted by family and placed in disposable plastic weighboats using Teflon-coated forceps or by hand while wearing disposable latex gloves. When possible, we collected replicate samples, multiple size classes within a taxon, or both to assess variations in concentration and to identify any relations of tissue concentrations to size. Organisms were thoroughly rinsed with deionized water and patted dry with a clean paper towel. Then, samples were sorted and composited by family with 
the goal of obtaining at least $1 \mathrm{~g}$ of wet biomass per sample. Each sample consisted of 3 to 15 individuals of the same family. Samples were weighed on an electronic balance $( \pm 0.01 \mathrm{~g})$ and placed in chemically cleaned glass jars with Teflon-lined lids. The lids were sealed with Parafilm, and the samples were frozen until they could be shipped to the analytical laboratory on April 13, 2010, for analysis of $\mathrm{Hg}_{\mathrm{T}}, \mathrm{MMeHg}$, and total solids.

\section{Analytical Methods}

\section{Sediments and Tailings}

Multielement analyses of all dry-sediment and tailings samples were performed in the laboratories of ALS CHEMEX. Bulk samples were ground in a zirconia ring mill and subjected to a near-total four-acid digestion. Major element concentrations were determined by ICP-AES; minor-element concentrations, other than $\mathrm{Hg}$, were determined by ICP-MS. Hg concentration was determined by cold-vapor atomic-absorption spectroscopy (CVAAS), following methods similar to those described by Crock (1996) and O'Leary and others (1996).

$\mathrm{Hg}$ and $\mathrm{MMeHg}$ analyses of all wet-sediment samples were performed at Brooks Rand Laboratories in Seattle, WA. Dry-sediment samples analyzed by ALS CHEMEX were also analyzed by Brooks Rand for Hg. For these analyses, the sediment was leached with cold aqua regia, followed by stannous chloride $\left(\mathrm{SnCl}_{2}\right)$ reduction, two-stage gold amalgamation, and coldvapor atomic-fluorescence spectroscopy (CVAFS) detection. Monomethylmercury was determined by acid bromide/methyl chloride extraction, followed by aqueous-phase ethylation, isothermal gas-chromatographic (GC) separation, and CVAFS detection (Horvat and others, 1993). Results reported on both a wet- and dry-weight basis are listed in Table 2 for analyses provided by Brooks Rand, and on a dry-weight basis for the analyses completed by ALS CHEMEX (tables 3, 4).

\section{Water}

Alkalinity (as $\mathrm{CaCO}_{3}$ ) was determined in the laboratory by titration with $\mathrm{H}_{2} \mathrm{SO}_{4}$, using Gran's technique (Orion Research, Inc., 1978), within 2-4 days after sample collection. Sulfate, chloride, nitrate, and fluoride concentrations were determined by ion chromatography (Fishman and Pyen, 1979).

Cations were analyzed by ICP-AES and ICP-MS. Ion chromatographic and alkalinity analyses were performed in USGS laboratories under the direction of Paul Lamothe, and ICPAES analyses were determined in USGS laboratories under the direction of Paul Briggs.

Duplicate water samples, blank samples, and USGS Water Resource Division standard reference waters were analyzed with the dataset.

At Brooks Rand, samples were handled in a Class-100 clean-air station that was monitored routinely for low levels of total gaseous $\mathrm{Hg}$. An ultraclean $\mathrm{Hg}$ trace-metal protocol was followed, including the use of rigorously cleaned and tested Teflon equipment and sample bottles and prescreened and purified reagents. Laboratory atmosphere and water supply were also routinely monitored for low levels of $\mathrm{Hg}$. Primary standards used in the laboratory were NIST certified or traceable to NIST certified materials. Following USEPA Method 1631, $\mathrm{MMeHg}$ standards were made from pure powder, calibrated against NBS-3133, and crossverified by daily analysis of Certified Reference Material DORM-2 (National Research Council 
of Canada Institute for National Measurement Standards, 1999). $\mathrm{Hg}_{\mathrm{T}}$ content was determined by bromine monochloride $(\mathrm{BrCl})$ oxidation followed by $\mathrm{SnCl}_{2}$ reduction, two-stage gold amalgamation, and CVAFS detection (Bloom and others, 1988). Monomethylmercury was liberated from water using an all-Teflon distillation system. Distilled samples were analyzed using aqueous-phase ethylation with purging onto Carbotrap, isothermal GC separation, and CVAFS detection (Bloom, 1989). To address accuracy and precision, quality-assurance measures were used with the following minimum frequency: laboratory duplicates, 1 per 10 samples; method blanks, three per analytical batch; filtration blanks, 1 per 10 samples; and spike recovery or standard reference material, 1 per 10 samples.

\section{Biota}

Samples were analyzed for $\mathrm{Hg}_{\mathrm{T}}$ and $\mathrm{MMeHg}$ at Brooks Rand Laboratory, Seattle, WA. A solid sample was homogenized, and an aliquot measured into a preweighed vessel, dried in an oven overnight, and weighed again, and, then, the percentage of dried solid material was calculated. This standard operating procedure (SOP), BR-1501, is analogous to EPA standard method $2540 \mathrm{G}$ (residue, total).

Once thawed, the samples were homogenized by using precleaned commercial-grade homogenization equipment. A homogenization blank was collected after cleaning the equipment and before homogenizing the samples. The blank was digested as a tissue sample and analyzed along with the associated homogenates. The result for the homogenization blank was less than 10 times the lowest sample result, indicating no significant contamination during homogenization (SOP BR-0106).

$\mathrm{Hg}_{\mathrm{T}}$ was determined as outlined in EPA method 1631 (SOP BR-0002). Samples were digested in nitric acid $\left(\mathrm{HNO}_{3}\right)$ and sulfuric acid $\left(\mathrm{H}_{2} \mathrm{SO}_{4}\right)$ and then further oxidized with bromine monochloride $(\mathrm{BrCl})$. Samples were analyzed by stannous chloride $\left(\mathrm{SnCl}_{2}\right)$ reduction, single gold amalgamation, and CVAFS detection using a BRL Model III CVAFS Mercury Analyzer. All sample results for low-level $\mathrm{Hg}$ analysis were blank corrected.

For $\mathrm{MMeHg}$ analysis, samples were prepared by potassium hydroxide $(\mathrm{KOH})$-methanol $\left(\mathrm{CH}_{3} \mathrm{OH}\right)$ digestion. Samples were analyzed by aqueous-phase ethylation, Tenax trap collection, GC separation, isothermal decomposition and CVAFS detection, using a BRL Model III CVAFS Mercury Analyzer. All sample results for low-level $\mathrm{Hg}$ analysis were blank corrected, as outlined in the calculations section of Brooks Rand SOP BR-0011.

Duplicate samples were analyzed at a rate of 5 percent, with at least one duplicate per matrix per analytical run to estimate the precision of the methods. The relative percent differences (RPD) for the $\mathrm{Hg}_{\mathrm{T}}$ duplicates ranged from 0.8 to 23 percent; the RPDs for all results were within the acceptable criterion (RPD $<30$ percent). The RPDs for invertebrate $\mathrm{MMeHg}$ duplicates ranged from 2 to 19 percent, all within the acceptable criterion of an RPD $<35$ percent.

To assure the accuracy of the methods, procedural blanks, spiked samples, and Standard Reference Materials were analyzed. To assure that no analyte was added during the processing of the sample, procedural blanks were analyzed at a rate of 5 percent of the total samples, with at least one blank per matrix per analytical run. The averages for the $\mathrm{Hg}_{\mathrm{T}}$ blanks ranged from 0.01 to $0.03 \mathrm{ng} / \mathrm{g}$, with method detection limits (MDL) of $0.04 \mathrm{ng} / \mathrm{g}$. The averages for MMeHg blanks ranged from 0.1 to $0.2 \mathrm{ng} / \mathrm{g}$, with an MDL of $1.0 \mathrm{ng} / \mathrm{g}$. All blank results were less than the acceptable criterion of twice the MDL. 
Spiked samples were analyzed at a rate of 5 percent, with at least one spike per matrix per analytical run. Spikes were samples fortified with a known quantity of analyte and analyzed as part of the run. The $\mathrm{Hg}_{\mathrm{T}}$ recovery ranged from 78 to 120 percent, with RPDs ranging from 0.2 to 13 percent; $\mathrm{MMeHg}$ recovery ranged from 67 to 130 percent. Although one sample had an unacceptable $\mathrm{MMeHg}$ recovery of 151 percent, reanalysis produced acceptable results. The MMeHg RPDs ranged from 0.1 to 20 percent. The results met the criterion of 70 to 130 -percent recovery with an $\mathrm{RPD}<30$ percent for $\mathrm{Hg}_{\mathrm{T}}$ and 65 to 135 percent with an $\mathrm{RPD}<35$ percent for $\mathrm{MMeHg}$.

Standard Reference Materials (DORM-3 2010) were analyzed at a rate of 5 percent to ensure that the method worked with naturally incorporated $\mathrm{Hg}$. $\mathrm{Hg}_{\mathrm{T}}$ recovery was 103 to 116 percent, within the criterion of 75 to 125 percent; MMeHg recovery was 80 to 93 percent, within the criterion of 65 to 135 percent.

\section{Results}

\section{Tailings at the Little Bonanza Mine Areas}

The $\mathrm{Hg}$ concentration in waste materials at the Little Bonanza Mine area varies in dependence on material type. Tailings (calcines) have the highest, and wasterock the lowest $\mathrm{Hg}$ concentrations. Ores processed in the three-pipe retort produced tailings that were disposed of in the flat area that extends from just west of the retort to WF Las Tablas Creek. The calcines, which are well exposed in the bank of WF Las Tablas Creek (fig. 9), consist of medium- to coarse-grained, well-stratified materials (fig. 12). Four samples of the calcines were collected in the exposure in WF Las Tablas Creek (fig. 11, samples 10LB9-10LB12). One grab sample that was taken at the uppermost exposure of the calcines (sample 10LB9) had an $\mathrm{Hg}_{\mathrm{T}}$ concentration of $101 \mathrm{ppm}$. Channel samples of the calcines were taken from the lower (sample 10LB11), middle (sample 10LB10), and upper part (sample 10LB12) parts of the exposure (table 1). The $\mathrm{Hg}_{\mathrm{T}}$ concentration in the calcines increases from $43.7 \mathrm{ppm}$ in the lower part, to $66 \mathrm{ppm}$ in the middle part, to $141 \mathrm{ppm}$ in the upper part of the section (table 2). The highest $\mathrm{Hg}_{\mathrm{T}}$ concentration is comparable to that in the grab sample taken from the top of the section.

Calcines with an $\mathrm{Hg}_{\mathrm{T}}$ concentration of $142 \mathrm{ppm}$ are present adjacent to the retort and are irregularly distributed in the upper $25 \mathrm{~cm}$ of the soil. Calcines in the three-pipe retort have an $\mathrm{Hg}_{\mathrm{T}}$ concentration of $27 \mathrm{ppm}$, and slag from the retort has a relatively low $\mathrm{Hg}_{\mathrm{T}}$ concentration of $1.79 \mathrm{ppm}$ and high iron (Fe) and manganese $(\mathrm{Mn})$ concentrations (table 2).

The calcines have elevated concentrations of Co (87 ppm), $\mathrm{Cr}(4,270 \mathrm{ppm})$, and $\mathrm{Ni}(2,410$ $\mathrm{ppm}$ ) that reflect the serpentinite host rock of the $\mathrm{Hg}$ mineralization (table 2). Exceptionally high $\mathrm{Mg}$ concentrations, up to 13.5 percent, are present in the calcines as a result of the presence of magnesite and serpentinite. No other trace elements are present in high concentrations. Gold was detected in six of the calcine samples, in concentrations ranging from 0.011 to $0.052 \mathrm{ppm}$. Trace metals that are moderately elevated and exceed the BLM Ecotoxicity screening criteria in calcines include As (13 ppm), $\mathrm{Cu}$ (48 ppm), $\mathrm{Pb}$ (109 ppm), and $\mathrm{Zn}$ (94 ppm, table 2); however, these elements do not exceed the BLM Camper screening criteria or the EPA preliminary remediation goals (PRGs).

Calcines and wasterock are present in the bank deposits of WF Las Tablas Creek upstream from the mine workings located on BLM lands at sample site 10BL3C (fig. 11). The 
calcines have an $\mathrm{Hg}_{\mathrm{T}}$ concentration of $108 \mathrm{ppm}$ and high $\mathrm{Co}, \mathrm{Cr}$, and $\mathrm{Ni}$ concentrations, similar to concentrations in the calcines exposed farther downstream at sample site 10LB9-12C.

\section{Sediment in WF Las Tablas Creek near the Little Bonanza Mine}

The headwaters of WF Las Tablas Creek begin above the Little Bonanza Mine area near an adit located at sample site 10LB2 (fig. 11). Sediment at the partially collapsed adit has a high $\mathrm{Hg}_{\mathrm{T}}$ concentration, $72 \mathrm{ppm}$ (table 3). Farther downstream, at sample site 10BL1 (figs. 11, 13), the stream sediment has an exceptionally high $\mathrm{Hg}$ concentration, $346 \mathrm{ppm}$ (table 2). This site is located just downstream from the calcines present in bank sediment at sample sites 10LB9 through 10LB12C. Farther downstream in WF Las Tablas Creek, at sample site 10LB4 (fig. 10), the $\mathrm{Hg}_{\mathrm{T}}$ concentration in sediment is still elevated, $44.9 \mathrm{ppm}$ (table 3). The sediment in the small tributary that drains the area of the collapsed dam (figs. 11, 14) has a low $\mathrm{Hg}$ concentration, $0.228 \mathrm{ppm}$, typical of background sediment concentrations (sample site 10LB3, table 3 ). The MMeHg concentration in sediment from WF Las Tablas Creek at all sample sites is relatively low, ranging from $0.042 \mathrm{ng} / \mathrm{g}$ to 0.304 at sample site $10 \mathrm{LB} 1$ (table 3).

\section{Water Chemistry}

All the waters in WF Las Tablas Creek in the mine area are alkaline as a result of the serpentinite that underlies most of the watershed and the presence of carbonate alteration in the mine area (table 1). The sulfate concentration in WF Las Tablas Creek waters is anomalous, ranging from 19 to $78 \mathrm{ppm}$. The highest sulfate concentration, $146 \mathrm{ppm}$, occurs in the waters being released from the adit at sample site 10LB2. High $\mathrm{Mg}$ and Ca concentrations are present in all waters, with the highest concentrations associated with mine drainage from the adit (tables 4 , 5). Dissolved organic carbon (DOC) concentration ranges from 2.6 to $6.6 \mathrm{ppm}$, comparable to those measured downstream from the Rinconada $\mathrm{Hg}$ mine (figs. 15, 16).

\section{$\mathrm{Hg}_{\mathrm{T}}$ and $\mathrm{MMeHg}$ in waters}

Under low flow conditions, the $\mathrm{Hg}_{\mathrm{T}}$ concentrations in water samples collected from WF Las Tablas Creek in the mine area are elevated, with the highest concentration, $96.2 \mathrm{ng} / \mathrm{L}$ at sample site 10LB1, located just below the exposure of calcines. At $2.5 \mathrm{~km}$ downstream from the mine area, at sample site $10 \mathrm{LB} 4, \mathrm{Hg}_{\mathrm{T}}$ concentration decreases considerably to $5.58-5.91 \mathrm{ng} / \mathrm{L}$ (table 3). The water emanating from the adit above the mine processing area has a relatively high $\mathrm{Hg}_{\mathrm{T}}$ concentration, $46.7 \mathrm{ng} / \mathrm{L}$, and the water that drains the breached dam in the mine area has a considerably lower but anomalous $\mathrm{Hg}_{\mathrm{T}}$ concentration, $17.4 \mathrm{ng} / \mathrm{L}$. The $\mathrm{Hg}_{\mathrm{T}}$ concentration in the filtered fraction varies, ranging from $13.5 \mathrm{ng} / \mathrm{L}$ in water from the adit to $67.6 \mathrm{ng} / \mathrm{L}$ at sample site 10LB1 (fig. 15). MMeHg concentrations in water from WF Las Tablas Creek and from the adit are all very low, ranging from $0.02 \mathrm{ng} / \mathrm{L}$ at the adit to $0.058 \mathrm{ng} / \mathrm{L}$ at sample site $10 \mathrm{LB} 1$. Although the waters have high $\mathrm{Hg}_{\mathrm{T}}$ concentrations, $\mathrm{MMeHg}$ concentrations are very low, constituting less than 1 percent of the total $\mathrm{Hg}$ present in the water column (fig. 16).

Under high-flow conditions, Hg concentrations in unfiltered and filtered waters are considerably higher at all sample sites than under low-flow conditions (fig. 19; table 8). Downstream from the adit, at sample site $11 \mathrm{LB} 2$, the $\mathrm{Hg}_{\mathrm{T}}$ concentrations in unfiltered and filtered waters are 190 and $51.8 \mathrm{ng} / \mathrm{L}$, respectively. Farther downstream, at sample site 11LB1, located in the mine processing area, the $\mathrm{Hg}_{\mathrm{T}}$ concentrations increase to $206 \mathrm{ng} / \mathrm{L}$ in unfiltered waters and decrease slightly in filtered water to $51.8 \mathrm{ng} / \mathrm{L}$. The $\mathrm{Hg}_{\mathrm{T}}$ concentrations in unfiltered 
waters decrease downstream from the mine area. At sample site 11LB4, located $1.25 \mathrm{~km}$ downstream from the mine area, the $\mathrm{Hg}_{\mathrm{T}}$ concentration is about two-thirds that in the mine area. At sample site $11 \mathrm{LB} 5$, located $2.5 \mathrm{~km}$ downstream from the mine area, the $\mathrm{Hg}_{\mathrm{T}}$ concentration decreases to about a third of that in the mine area (fig. 19). Hg concentrations in filtered waters decrease downstream from the mine area but account for an increasing amount of the total $\mathrm{Hg}$ present at each site. $\mathrm{MMeHg}$ concentrations are considerably higher under high-flow conditions than under low-flow conditions, ranging from 0.163 to $0.236 \mathrm{ng} / \mathrm{L}$; however, no systematic variation in $\mathrm{MMeHg}$ concentrations was observed.

\section{$\mathrm{Hg}_{\mathrm{T}}$ and $\mathrm{MMeHg}$ in Biota}

We collected composite samples of aquatic invertebrates (table 6), for analyses of $\mathrm{Hg}_{\mathrm{T}}$ and $\mathrm{MMeHg}$ from one sample site (LBUP) at the Little Bonanza Mine and another downstream (LBBR) on April 6, 2010.

The highest $\mathrm{Hg}_{\mathrm{T}}$ concentration $(0.446 \mu \mathrm{g} / \mathrm{g}$ wet weight (ww)) was measured in a composite sample of six dobsonfly larvae (family Corydalidae) collected from Little Bonanza upstream (LBUP); the lowest $\mathrm{Hg}_{\mathrm{T}}$ concentration was measured in a sample of six dragonfly larvae (Aeshnidae) from the downstream site, Little Bonanza at the bridge (LBBR) $(0.118 \mu \mathrm{g} / \mathrm{g}$ ww). The highest MMeHg concentration $(0.148 \mu \mathrm{g} / \mathrm{g} \mathrm{ww})$ was measured in dragonfly larvae (Gomphidae) collected from LBBR; the lowest MMeHg concentration was measured in a sample of three dobsonfly larvae from LBUP $(0.057 \mu \mathrm{g} / \mathrm{g} w w)$.

$\mathrm{MMeHg}$ in the two dobsonfly samples collected from LBUP averaged 18.1 percent, whereas that in the same taxa at LBBR was 42.0 percent. $\mathrm{MMeHg}$ in other taxa collected from LBBR ranged from 66.5 percent in Gerridae to 77.5 percent in Aeshnidae.

The only taxon collected at both sites was dobsonflies. The average $\mathrm{Hg}_{\mathrm{T}}$ and $\mathrm{MMeHg}$ concentrations at LBUP were 0.0795 and $0.439 \mu \mathrm{g} / \mathrm{g}$, respectively. The comparable concentrations in dobsonflies from LBBR were 0.057 and $0.136 \mu \mathrm{g} / \mathrm{g}$, lower by 28 and 69 percent, respectively, than at LBUP.

\section{Conclusions}

Past mining and mine wastes at the Little Bonanza $\mathrm{Hg}$ mine have contaminated sediment in WF Las Tablas Creek with high $\mathrm{Hg}_{\mathrm{T}}$ concentrations. A significant amount of calcines still remains at the Little Bonanza $\mathrm{Hg}$ mine and continues to contribute $\mathrm{Hg}$-enriched sediment to the creek. The calcines are well exposed in the bank of WF Las Tablas Creek, and the flat area extending eastward from the exposures in the creek toward the remains of the retort is likely underlain by calcines. Test pits in this area would be necessary to determine the extent and volume of the calcines that may be present in the area.

Although the calcines have only moderately high $\mathrm{Hg}_{\mathrm{T}}$ concentrations, 43 to $141 \mathrm{ppm}$, the $\mathrm{Hg}_{\mathrm{T}}$ concentration in the sediment of WF Las Tablas Creek in the mine area is extremely high (max. $304 \mathrm{ppm}$ at sample site $10 \mathrm{LB} 1$ ). $\mathrm{Hg}_{\mathrm{T}}$ concentrations higher than $100 \mathrm{ppm}$ in sediment are rare downstream from $\mathrm{Hg}$ mines in the Coast Ranges. Only one tributary that drains the Petray Mine in the Cache Creek Watershed, Colusa County, California, is reported to have similarly high $\mathrm{Hg}_{\mathrm{T}}$ concentrations in stream sediments (Slowey and Rytuba, 2008). At sample site 10LB4, located about $2.5 \mathrm{~km}$ downstream from the mine area, the $\mathrm{Hg}_{\mathrm{T}}$ concentration in sediment is still very high, $44.9 \mathrm{ppm}$. The $\mathrm{Hg}_{\mathrm{T}}$ concentration in calcines is not sufficiently high to account for the high $\mathrm{Hg}_{\mathrm{T}}$ concentrations in sediment. An unmined $\mathrm{Hg}$ mineralized zone is likely being eroded 
and contributing Hg-enriched sediment to the creek. The calcines also have very high $\mathrm{Mg}$ concentrations and elevated $\mathrm{Co}, \mathrm{Cr}$, and $\mathrm{Ni}$ concentrations that reflect the serpentinite host rock. Other trace metals in the calcines are absent in concentrations of significant environmental concern.

The $\mathrm{Hg}_{\mathrm{T}}$ concentrations in water samples collected from WF Las Tablas Creek in and downstream from the mine area are extremely high under both low- and high-flow conditions. The high-flow $\mathrm{Hg}_{\mathrm{T}}$ concentrations are comparable to those measured downstream from some of the larger $\mathrm{Hg}$ mines in the Coast Ranges, including the Rinconada $\mathrm{Hg}$ mine (fig. 15). The calcines present in bank deposits contribute to the high $\mathrm{Hg}_{\mathrm{T}}$ and Total Suspended Solids (TSS) concentrations. Effluent from the adit also contributes $\mathrm{Hg}$ to the creek, but most $\mathrm{Hg}$ from the adit is in the filtered fraction and consists of colloidal and dissolved $\mathrm{Hg}$ phases. $\mathrm{The}_{\mathrm{Hg}}$ concentration in waters in the mine area does not meet the 50-ng/L EPA criterion (EPA, 1999) and is above the water-quality objective of $12 \mathrm{ng} / \mathrm{L}$ under both high- and low-flow conditions. However, under low-flow conditions, the MMeHg concentrations in the waters of WF Las Tablas Creek are very low, lower than in all waters sampled downstream from the Rinconada $\mathrm{Hg}$ mine under all flow conditions (fig. 16). Under high-flow conditions, $\mathrm{MMeHg}$ concentrations are considerably higher, comparable to those measured downstream from the Rinconada $\mathrm{Hg}$ mine.

The percentages of $\mathrm{Hg}$ present as $\mathrm{MMeHg}$ in the stream-sediment samples are all very low, ranging from 0.0001 to 0.01 (fig. 17). The percentage of $\mathrm{MMeHg}(\% \mathrm{MMeHg}$ ) in sediment (fig. 18, table 3) can be used as an indicator for net production of $\mathrm{MMeHg}$ when $\mathrm{MMeHg}$ is normalized to $\mathrm{Hg}_{\mathrm{T}}$ (Drott and others, 2008). The \% $\mathrm{MMeHg}$ is calculated by dividing the measured $\mathrm{MMeHg}$ concentrations in sediment by the $\mathrm{Hg}_{\mathrm{T}}$ concentration present in the same sample:

$$
\% \mathrm{MMeHg}=(\mathrm{MMeHg}, \text { in } \mathrm{ng} / \mathrm{g} \text { in sediment }) /\left(\mathrm{Hg}_{\mathrm{T}}, \text { in } \mathrm{ng} / \mathrm{g} \text { in sediment }\right)
$$

The very low \%MMeHg in stream sediment in WF Las Tablas Creek (table 3, fig. 18) indicates that methylation of $\mathrm{Hg}$ is not favorable in the mine area. Because there are adequate concentrations of $\mathrm{SO}_{4}$ and DOC in the water for sulfate reducing bacteria to methylate $\mathrm{Hg}$, the low $\mathrm{MMeHg}$ concentrations may result from the $\mathrm{Hg}$ phase in the creek sediment not being bioaccessible, as would be the case if cinnabar were the primary phase in the sediment.

Invertebrates collected from the mine area at sample site 10LB1 had elevated $\mathrm{Hg}_{\mathrm{T}}$ concentrations, but $\mathrm{MMeHg}$ concentrations were similar to those observed at the downstream sample site (10LB4) and in a nearby Hg-mine impacted stream (Rinconada Creek). The $\% \mathrm{MMeHg}$ at sample site 10LB1 averaged about 18 percent, consistent with the low observed $\% \mathrm{MMeHg}$ in sediment at that site. Although the $\mathrm{MMeHg}$ concentrations in the invertebrates collected from the downstream site were similar to those from sample site $10 \mathrm{LB} 1$, the $\% \mathrm{MMeHg}$ in invertebrates from the lower site was nearly 4 times greater, relating to the lower $\mathrm{Hg}_{\mathrm{T}}$ concentration in sediment at the lower site. $\mathrm{MMeHg}$ concentrations in water were similar at the two sites, but $\mathrm{Hg}_{\mathrm{T}}$ concentration in the water at the minesite was 17 times greater than at the lower site. Overall, the $\mathrm{MMeHg}$ concentrations in invertebrates from the Little Bonanza sites were 2.5 to 6 times higher than in similar taxa collected from a nearby stream not impacted by $\mathrm{Hg}$ mining (Trout Creek). Transport of $\mathrm{Hg}$ in creek waters depends on flow conditions; the highest concentrations and greatest transport of $\mathrm{Hg}$ occur under high-flow conditions. The high $\mathrm{Hg}_{\mathrm{T}}$ concentrations in sediment in WF Las Tablas Creek in the mine area and the elevated $\mathrm{Hg}_{\mathrm{T}}$ concentrations under low-flow conditions sampled during this study indicate that very high $\mathrm{Hg}$ 
concentrations are potentially transported from the mine area during high-flow events. Thus, although the Little Bonanza Mine has a small volume of calcines, it may release a significant amount of $\mathrm{Hg}$ to downstream environments during high-flow events. We recommend that at least one high-flow sampling be done during a winter storm to assess the magnitude of $\mathrm{Hg}$ release from the mine area.

\section{Acknowledgments}

We appreciate the guidance and assistance provided by Kent Varvel of the Bakersfield Field Office of the BLM.

\section{References Cited}

Bloom, N.S., 1989, Determination of picogram levels of methylmercury by aqueous phase ethylation, followed by cryogenic gas chromatography with cold vapour atomic fluorescence detection: Canadian Journal of Fisheries and Aquatic Sciences, v. 46, p. 1131-1140.

Bloom, N.S., 1995, Mercury as a case study of ultra-clean sample handling and storage in aquatic trace metal research: Environmental Laboratory, v. 3-4, p. 20-25.

Bloom, N.S., Crecelius, E.A., and Fitzgerald, W.F., 1988, Determination of volatile mercury species at the picogram level by low temperature gas chromatography with cold vapor atomic fluorescence detection: Analytica Chimica Acta, v. 208, p. 151-161.

Crock, J.G., 1996, Mercury, Chapter 29 of Sparks, D.L., ed., Chemical methods, pt. 3 of Methods of soil analysis: Soil Science Society of America Book Series, no. 5, p. 769-791.

Drott, A., Lambertsson, L., Björn, E., and Skyllberg, U., 2008, Do potential methylation rates reflect accumulated methyl mercury in contaminated sediments?: Environmental Science \& Technology, v. 42, p. 153-158.

Fishman, M.J. and Pyen, G., 1979, Determination of selected anions in water by ion chromatography: U.S. Geological Survey Techniques of Water Resources Investigations 79-101, $30 \mathrm{p}$.

Gill, G.A., and Fitzgerald, W.F., 1987, Picomolar mercury measurements in seawater and other materials using stannous chloride reduction and twostage gold amalgamation with gas phase detection: Marine Chemistry, v. 20, p. $227-243$. 
Horvat, M., Bloom, N.S., and Liang, L., 1993, Comparison of distillation with other current isolation methods for the determination of methyl mercury compounds in low level environmental samples. Part 1, Sediments:

Analytica Chimica Acta, v. 281, p. 135-152.

National Research Council of Canada, Institute for National Measurement Standards, 1999, DORM-2, DOLT-2, Dogfish muscle and liver certified reference materials for trace metals: Certified Reference Materials Data Sheet, 4 p. [http://www.ems.nrc.ca/ems1.htm, accessed January 28, 2009].

O'Leary, R.M., Hageman, P.L., and Crock, J.G., 1996, Determination of mercury in water, geologic, and plant materials by continuous flow-cold vaporatomic absorption spectrophotometry, in Arbogast, B.F., ed., Quality assurance manual for the branch of geochemistry; United States Geological Survey: U.S. Geological Survey Open-File Report 96-525, p. 42-55.

Orion Research, Inc., 1978, Analytical methods guide ( $9^{\text {th }}$ ed.): Cambridge, Mass., 48 p.

Slowey, A.J., and Rytuba, J.J., 2008, Mercury release from the Rathburn Mine, Petray Mine, and Bear Valley saline springs, Colusa County, California, 2004-2006: U.S. Geological Survey Open-File Report 2008-1179, 49 p. [http://pubs.usgs.gov/of/2008/1179/].

Yates, R.G., Eckel, E.B. and Granger, A.E., 1941, Quicksilver deposits in San Luis Obispo County and southwestern Monterey County, California: U.S. Geological Survey Bulletin 922-R, p. 564-565. 
Table 1. Sample locations and physical and selected chemical parameters for waters from the Little Bonanza Min

\begin{tabular}{|c|c|c|c|c|c|c|}
\hline $\begin{array}{l}\text { Site } \\
\text { Water and } \\
\text { sediments }\end{array}$ & $\begin{array}{l}\text { Site } \\
\text { Biota }\end{array}$ & Latitude & Longitude & Sample Site Description & \multicolumn{2}{|c|}{$\begin{array}{l}\text { Conductivity } \\
\text { micro Siemens }\end{array}$} \\
\hline \multicolumn{7}{|c|}{ WF Las Tablas Creek } \\
\hline 10LB1A & LBUP & 35.58414 & -120.91121 & Little Bonanza Creek & \multicolumn{2}{|c|}{772} \\
\hline \multirow[t]{2}{*}{$10 \mathrm{LB} 4 \mathrm{~A}$} & LBBR & 35.59845 & -120.91093 & WF Las Tablas Creek & & \\
\hline & & \multicolumn{5}{|c|}{ Mine Drainage from Adit } \\
\hline $10 \mathrm{LB} 2 \mathrm{~A}$ & & Reservoir Creek & -120.91109 & Mine adit drainage & \multicolumn{2}{|c|}{1,142} \\
\hline $10 \mathrm{LB} 3 \mathrm{~A}$ & & $\begin{array}{r}35.58424 \\
\text { Little Bonan }\end{array}$ & $\begin{array}{l}-120.90997 \\
\text { alcines and } w\end{array}$ & Reservoir drainage & \multicolumn{2}{|c|}{318} \\
\hline 10LB3C & & 35.58393 & -120.91101 & $\begin{array}{l}\text { Calcines in creek bank near pipe d } \\
\text { from adit }\end{array}$ & & \\
\hline 10LB4C & & 35.58355 & -120.91033 & Waste rock and some calcines & & \\
\hline 10LB5C & & 35.58397 & -120.91080 & Slag from retort & & \\
\hline 10LB6C & & 35.58397 & -120.91080 & Roasted ore from retort & & \\
\hline 10LB7C & & 35.58397 & -120.91080 & $\begin{array}{l}\text { Calcines adjacent to retort about } 2 \\
\text { thick }\end{array}$ & & \\
\hline 10LB8C & & 35.58382 & -120.91068 & Waste rock on disturbed slope abo & tort & \\
\hline 10LB9C & & 35.5838 & -120.91103 & $\begin{array}{l}\text { Calcines exposed in bank of creek } \\
\text { retort }\end{array}$ & & \\
\hline 10LB10C & & 35.58393 & -120.91101 & $\begin{array}{l}\text { Calcines in bank of creek west of } \\
\text { middle } 0.75 \mathrm{~m}\end{array}$ & & \\
\hline $10 \mathrm{LB} 11 \mathrm{C}$ & & 35.58393 & -120.91101 & $\begin{array}{l}\text { Calcines in bank of creek west of } \\
\text { bottom } 0.5 \mathrm{~m}\end{array}$ & & \\
\hline \multirow[t]{3}{*}{ 10LB12C } & & 35.58393 & -120.91101 & $\begin{array}{l}\text { Calcines in bank of creek west of } \\
\text { top } 0.5 \mathrm{~m}\end{array}$ & & \\
\hline & \multicolumn{3}{|c|}{ Trout Creek Reference site } & & & \\
\hline & TRCR & 35.38875 & -120.58167 & Trout Creek reference site & 120.58167 & 120.5 \\
\hline
\end{tabular}


Table 2. Mercury and associated major and minor elements in sediment, precipitates, and calcines from the Little Bonanza Mine.

\begin{tabular}{|c|c|c|c|c|c|c|c|}
\hline $\begin{array}{c}\text { Field } \\
\text { Number }\end{array}$ & Latitude & Longitude & Date & Sample Site Description & $\begin{array}{c}\mathrm{Hg} \\
\mathrm{ppm}\end{array}$ & $\begin{array}{c}\mathrm{Ag} \\
\mathrm{ppm}\end{array}$ & $\begin{array}{l}\mathrm{Al} \\
\% \\
\end{array}$ \\
\hline & \multicolumn{7}{|c|}{ WF Las Tablas Creek } \\
\hline 10LB1A & 35.58414 & -120.91121 & $4 / 6 / 10$ & Little Bonanza Creek & 346 & 0.04 & 6.78 \\
\hline \multirow[t]{2}{*}{ 10LB4A } & 35.59845 & -120.91093 & $4 / 6 / 10$ & WF Las Tablas Creek & 3.79 & 0.08 & 7.2 \\
\hline & \multicolumn{7}{|c|}{ Mine Drainage from Adit } \\
\hline \multirow[t]{2}{*}{$10 \mathrm{LB} 2 \mathrm{~A}$} & 35.583 & -120.91109 & $4 / 6 / 10$ & Mine adit drainage & 292 & 0.05 & 7.4 \\
\hline & \multicolumn{7}{|c|}{ Reservoir Creek } \\
\hline $10 \mathrm{LB} 3 \mathrm{~A}$ & 35.58424 & -120.90997 & $4 / 6 / 10$ & Reservoir drainage & 0.25 & 0.05 & 7.39 \\
\hline & \multicolumn{7}{|c|}{ Little Bonanza calcines and waste rock } \\
\hline 10LB3C & 35.58393 & -120.91101 & & Calcines in creek bank near pipe down from adit & 108.5 & 0.07 & 3.53 \\
\hline $10 \mathrm{LB} 4 \mathrm{C}$ & 35.58355 & -120.91033 & & Waste rock and some calcines & 30.3 & 0.03 & 1.2 \\
\hline 10LB5C & 35.58397 & -120.91080 & & Slag from retort & 1.79 & 0.16 & 0.12 \\
\hline 10LB6C & 35.58397 & -120.91080 & & Roasted ore from retort & 27.2 & 0.05 & 0.48 \\
\hline $10 \mathrm{LB} 7 \mathrm{C}$ & 35.58397 & -120.91080 & & Calcines adjacent to retort about $25 \mathrm{~cm}$ thick & 142.5 & 0.12 & 2.31 \\
\hline 10LB8C & 35.58382 & -120.91068 & & Waste rock on disturbed slope above retort & 0.29 & 0.07 & 5.09 \\
\hline 10LB9C & 35.5838 & -120.91103 & & Calcines exposed in bank of creek west of retort & 101 & 0.08 & 5.2 \\
\hline 10LB10C & 35.58393 & -120.91101 & & Calcine in bank of creek west of retort, middle $0.75 \mathrm{~m}$ & 66.2 & 0.02 & 1.08 \\
\hline 10LB11C & 35.58393 & -120.91101 & & Calcine in bank of creek west of retort, bottom $0.5 \mathrm{~m}$ & 43.7 & 0.03 & 1.39 \\
\hline 10LB12C & 35.58393 & -120.91101 & & Calcine in bank of creek west of retort, top $0.5 \mathrm{~m}$ & 141 & 0.03 & 1.36 \\
\hline
\end{tabular}




\section{Table 2 (cont'd)}

\begin{tabular}{|c|c|c|c|c|c|c|c|c|c|c|c|c|c|c|c|c|}
\hline Field Number & $\begin{array}{c}\text { As } \\
\text { ppm }\end{array}$ & $\begin{array}{c}\mathrm{Ba} \\
\mathrm{ppm}\end{array}$ & $\begin{array}{c}\mathrm{Be} \\
\mathrm{ppm}\end{array}$ & $\begin{array}{c}\mathrm{Bi} \\
\mathrm{ppm}\end{array}$ & $\begin{array}{c}\mathrm{Ca} \\
\%\end{array}$ & $\begin{array}{c}\text { Cd } \\
\text { ppm }\end{array}$ & $\begin{array}{c}\mathrm{Ce} \\
\mathrm{ppm}\end{array}$ & $\begin{array}{c}\text { Co } \\
\text { ppm }\end{array}$ & $\begin{array}{c}\mathrm{Cr} \\
\mathrm{ppm}\end{array}$ & $\begin{array}{c}\text { Cs } \\
\text { ppm }\end{array}$ & $\begin{array}{c}\mathrm{Cu} \\
\mathrm{ppm}\end{array}$ & $\begin{array}{l}\mathrm{Fe} \\
\%\end{array}$ & $\begin{array}{c}\mathrm{Ga} \\
\mathrm{ppm}\end{array}$ & $\begin{array}{c}\mathrm{Ge} \\
\mathrm{ppm}\end{array}$ & $\begin{array}{c}\mathrm{Hf} \\
\mathrm{ppm}\end{array}$ & $\begin{array}{c}\text { In } \\
\text { ppm }\end{array}$ \\
\hline \multicolumn{17}{|c|}{ WF Las Tablas Creek } \\
\hline 10LB1A & 10.4 & 680 & 0.97 & 0.21 & 1.11 & 0.17 & 32.6 & 52.9 & 1,490 & 5.58 & 55.5 & 6.11 & 16.2 & 0.1 & 2.3 & 0.065 \\
\hline 10LB4A & 11.7 & 460 & 1.16 & 0.25 & 1.32 & 0.16 & 39.7 & 37.7 & 280 & 5.13 & 47.9 & 5.32 & 17.35 & 0.15 & 2.4 & 0.066 \\
\hline \multicolumn{17}{|c|}{ Mine Drainage from Adit } \\
\hline 10LB2A & 9.5 & 400 & 0.99 & 0.19 & 0.7 & 0.08 & 32.3 & 40.2 & 663 & 13.55 & 56.5 & 5.41 & 18 & 0.16 & 2 & 0.072 \\
\hline \multicolumn{17}{|c|}{ Reservoir Creek } \\
\hline 10LB3A & 12.1 & 590 & 1.23 & 0.3 & 1.1 & 0.11 & 38.7 & 34.1 & 464 & 5.72 & 44.9 & 4.92 & 18.3 & 0.15 & 2.4 & 0.063 \\
\hline \multicolumn{17}{|c|}{ Little Bonanza calcines and waste rock } \\
\hline 10LB3C & 13.2 & 190 & 0.68 & 0.09 & 0.84 & 0.05 & 8.07 & 123 & 2,910 & 5.76 & 22.1 & 7.25 & 9.97 & 0.19 & 1.2 & 0.03 \\
\hline 10LB4C & 11 & 320 & 0.4 & 0.03 & 1.14 & 0.03 & 5.13 & 86.4 & 2,910 & 2.26 & 13.5 & 4.56 & 3.18 & 0.08 & 0.3 & 0.01 \\
\hline 10LB5C & 5.3 & 10 & 0.05 & 0.01 & 0.08 & 0.02 & 1.08 & 27 & 70 & 0.07 & 78.9 & $>50$ & 7.62 & 1.97 & 0.1 & 0.005 \\
\hline 10LB6C & 8.3 & 80 & 0.3 & 0.03 & 2.36 & 0.04 & 1.91 & 87.1 & 2,050 & 1.28 & 9.2 & 4.69 & 1.9 & 0.1 & 0.1 & 0.006 \\
\hline 10LB7C & 11 & 360 & 0.48 & 0.18 & 7.13 & 0.24 & 10.35 & 69.7 & 4,270 & 3.61 & 39.6 & 6.34 & 5.82 & 0.12 & 0.8 & 0.029 \\
\hline 10LB8C & 4 & 330 & 0.64 & 0.11 & 2.37 & 0.09 & 20.1 & 40.3 & 659 & 3.46 & 44.4 & 4.92 & 12.25 & 0.11 & 1.6 & 0.044 \\
\hline 10LB9C & 12.6 & 340 & 0.74 & 0.1 & 1.5 & 0.1 & 25 & 48.9 & 788 & 5.15 & 48.1 & 5.74 & 11.1 & 0.13 & 1.7 & 0.052 \\
\hline 10LB10C & 3.7 & 120 & 0.37 & 0.02 & 0.95 & 0.02 & 4.62 & 77.9 & 2,480 & 1.58 & 16.1 & 4.45 & 2.97 & 0.1 & 0.3 & 0.011 \\
\hline $10 \mathrm{LB} 11 \mathrm{C}$ & 4.1 & 130 & 0.4 & 0.03 & 1.38 & 0.04 & 6.02 & 71.7 & 2,080 & 1.84 & 15.9 & 4.2 & 3.68 & 0.12 & 0.4 & 0.013 \\
\hline $10 \mathrm{LB} 12 \mathrm{C}$ & 3.5 & 100 & 0.36 & 0.03 & 0.88 & 0.04 & 6.54 & 71.6 & 1,820 & 1.88 & 13.8 & 4.31 & 3.3 & 0.1 & 0.4 & 0.015 \\
\hline
\end{tabular}


Table 2 (cont'd)

\begin{tabular}{|c|c|c|c|c|c|c|c|c|c|c|c|c|c|c|c|c|}
\hline Field Number & $\begin{array}{l}\mathrm{K} \\
\%\end{array}$ & $\begin{array}{c}\text { La } \\
\text { ppm }\end{array}$ & $\begin{array}{c}\mathrm{Li} \\
\mathrm{ppm}\end{array}$ & $\begin{array}{c}\mathrm{Mg} \\
\%\end{array}$ & $\begin{array}{c}\mathrm{Mn} \\
\mathrm{ppm}\end{array}$ & $\begin{array}{c}\text { Mo } \\
\text { ppm }\end{array}$ & $\begin{array}{c}\mathrm{Na} \\
\%\end{array}$ & $\begin{array}{c}\mathrm{Nb} \\
\mathrm{ppm}\end{array}$ & $\begin{array}{c}\mathrm{Ni} \\
\mathrm{ppm}\end{array}$ & $\begin{array}{c}P \\
\text { ppm }\end{array}$ & $\begin{array}{c}\mathrm{Pb} \\
\mathrm{ppm}\end{array}$ & $\begin{array}{c}\mathrm{Rb} \\
\mathrm{ppm}\end{array}$ & $\begin{array}{c}\mathrm{Re} \\
\mathrm{ppm}\end{array}$ & $\begin{array}{l}\mathrm{S} \\
\%\end{array}$ & $\begin{array}{c}\mathrm{Sb} \\
\mathrm{ppm}\end{array}$ & $\begin{array}{c}\mathrm{Se} \\
\mathrm{ppm}\end{array}$ \\
\hline \multicolumn{17}{|c|}{ "WF Las Tablas Creek } \\
\hline 10LB1A & 1.08 & 13.9 & 61.2 & 4.08 & 1250 & 0.93 & 1.12 & 7.4 & 429 & 510 & 12.8 & 56.1 & $<0.002$ & 0.04 & 1.1 & 2 \\
\hline 10LB4A & 1.43 & 19.1 & 52.3 & 3.07 & 1010 & 0.94 & 1.47 & 9.3 & 268 & 540 & 15.6 & 75.5 & $<0.002$ & 0.01 & 1.49 & 2 \\
\hline \multicolumn{17}{|c|}{ Mine Drainage from Adit } \\
\hline 10LB2A & 1.17 & 15.5 & 113.5 & 1.21 & 773 & 1.06 & 0.8 & 7.8 & 592 & 550 & 9.9 & 75.8 & $<0.002$ & 0.03 & 1.03 & 2 \\
\hline \multicolumn{17}{|c|}{ Reservoir Creek } \\
\hline 10LB3A & 1.57 & 19.1 & 50.3 & 3.27 & 878 & 0.86 & 1.38 & 9.3 & 248 & 540 & 16 & 82.5 & $<0.002$ & 0.01 & 1.58 & 2 \\
\hline \multicolumn{17}{|c|}{ Little Bonanza calcines and waste rock } \\
\hline 10LB3C & 0.59 & 4.2 & 64 & 4.73 & 1030 & 0.67 & 0.06 & 2 & 2,410 & 190 & 4.4 & 42 & $<0.002$ & 0.08 & 0.73 & 1 \\
\hline 10LB4C & 0.19 & 2.5 & 36.1 & 11.05 & 643 & 0.25 & 0.1 & 1.1 & 1,790 & 110 & 2.9 & 11.6 & $<0.002$ & 0.13 & 0.49 & 1 \\
\hline 10LB5C & 0.02 & 0.5 & 0.7 & 0.07 & 3690 & 4.11 & 0.02 & 1.1 & 29.3 & 310 & 6.2 & 1.1 & 0.004 & 0.07 & 0.4 & 1 \\
\hline 10LB6C & 0.06 & 0.9 & 34 & 12.6 & 769 & 0.91 & 0.04 & 0.4 & 1,695 & 90 & 100.5 & 3.3 & $<0.002$ & 0.1 & 4.43 & 1 \\
\hline 10LB7C & 0.32 & 5 & 33.7 & 8.51 & 918 & 2.19 & 0.35 & 3.1 & 1,150 & 330 & 109 & 18.5 & $<0.002$ & 0.08 & 5.13 & 1 \\
\hline 10LB8C & 0.58 & 9.3 & 59 & 9.46 & 843 & 0.38 & 0.22 & 5.1 & 626 & 460 & 6.3 & 27.6 & $<0.002$ & 0.01 & 0.5 & 1 \\
\hline 10LB9C & 0.75 & 10.9 & 65.4 & 4.49 & 1060 & 0.85 & 0.65 & 5.1 & 612 & 450 & 9.5 & 41 & $<0.002$ & 0.04 & 1.22 & 1 \\
\hline 10LB10C & 0.15 & 2 & 37 & 13.55 & 616 & 0.29 & 0.17 & 1 & 1,530 & 100 & 3 & 9 & $<0.002$ & 0.11 & 0.41 & 1 \\
\hline 10LB11C & 0.19 & 2.7 & 34.3 & 11.25 & 637 & 0.36 & 0.16 & 1.3 & 1,415 & 120 & 2.6 & 11.4 & $<0.002$ & 0.08 & 0.39 & 1 \\
\hline $10 \mathrm{LB} 12 \mathrm{C}$ & 0.21 & 2.9 & 37.7 & 13.4 & 668 & 0.27 & 0.16 & 1.3 & 1,440 & 140 & 3.1 & 11.6 & $<0.002$ & 0.12 & 0.41 & 1 \\
\hline
\end{tabular}


Table 2 (cont'd)

\begin{tabular}{|c|c|c|c|c|c|c|c|c|c|c|c|c|c|c|}
\hline Field Number & $\begin{array}{c}\text { Sn } \\
\text { ppm }\end{array}$ & $\begin{array}{c}\mathrm{Sr} \\
\mathrm{ppm}\end{array}$ & $\begin{array}{c}\mathrm{Ta} \\
\mathrm{ppm}\end{array}$ & $\begin{array}{c}\text { Te } \\
\text { ppm }\end{array}$ & $\begin{array}{c}\text { Th } \\
\text { ppm }\end{array}$ & $\begin{array}{l}\mathrm{Ti} \\
\%\end{array}$ & $\begin{array}{c}\mathrm{TI} \\
\mathrm{ppm}\end{array}$ & $\begin{array}{c}\mathrm{U} \\
\mathrm{ppm}\end{array}$ & $\begin{array}{c}\mathrm{V} \\
\mathrm{ppm}\end{array}$ & $\begin{array}{c}\text { W } \\
\text { ppm }\end{array}$ & $\begin{array}{c}\mathrm{Y} \\
\mathrm{ppm}\end{array}$ & $\begin{array}{c}\mathrm{Zn} \\
\mathrm{ppm}\end{array}$ & $\begin{array}{c}\mathrm{Zr} \\
\mathrm{ppm}\end{array}$ & $\begin{array}{c}\mathrm{Au} \\
\mathrm{ppm}\end{array}$ \\
\hline \multicolumn{15}{|c|}{ "WF Las Tablas Creek } \\
\hline 10LB1A & 1.6 & 129 & 0.44 & $<0.05$ & 4.7 & 0.457 & 0.39 & 1.4 & 143 & 1.1 & 21.8 & 108 & 79.9 & 0.009 \\
\hline 10LB4A & 1.9 & 127 & 0.59 & 0.05 & 7.2 & 0.456 & 0.48 & 2.2 & 131 & 1.4 & 21.1 & 101 & 77.5 & 0.005 \\
\hline \multicolumn{15}{|c|}{ Mine Drainage from Adit } \\
\hline 10LB2A & 1.5 & 248 & 0.47 & 0.05 & 5 & 0.497 & 0.53 & 1.3 & 151 & 1.1 & 21.7 & 88 & 64.9 & 0.008 \\
\hline \multicolumn{15}{|c|}{ Reservoir Creek } \\
\hline 10LB3A & 2.1 & 107 & 0.61 & $<0.05$ & 7.9 & 0.432 & 0.51 & 2.3 & 125 & 1.7 & 21.1 & 97 & 79.2 & 0.004 \\
\hline \multicolumn{15}{|c|}{ Little Bonanza calcines and waste rock } \\
\hline 10LB3C & 0.8 & 105.5 & 0.13 & $<0.05$ & 1.6 & 0.125 & 0.53 & 0.6 & 88 & 0.6 & 9.4 & 75 & 41.8 & 0.001 \\
\hline 10LB4C & 0.3 & 117.5 & 0.07 & $<0.05$ & 0.8 & 0.064 & 0.2 & 0.4 & 39 & 0.3 & 3.3 & 50 & 12.5 & 0.001 \\
\hline 10LB5C & 3.1 & 5.9 & $<0.05$ & 0.17 & 0.2 & 0.007 & $<0.02$ & 0.7 & 62 & 6.2 & 0.5 & $<2$ & 2.7 & $<0.001$ \\
\hline 10LB6C & 0.4 & 135.5 & $<0.05$ & $<0.05$ & 0.2 & 0.021 & 0.21 & 0.2 & 29 & 0.7 & 1.5 & 45 & 4.5 & $<0.001$ \\
\hline $10 \mathrm{LB} 7 \mathrm{C}$ & 1.4 & 320 & 0.18 & 0.05 & 1.3 & 0.163 & 0.34 & 4.5 & 78 & 9.7 & 8.2 & 94 & 30.1 & 0.001 \\
\hline 10LB8C & 0.9 & 384 & 0.33 & 0.05 & 3.4 & 0.3 & 0.15 & 1.1 & 97 & 0.7 & 16 & 79 & 58.3 & $<0.001$ \\
\hline 10LB9C & 1 & 156 & 0.34 & 0.06 & 3.3 & 0.365 & 0.32 & 1.1 & 117 & 0.8 & 16.6 & 88 & 58.8 & $<0.001$ \\
\hline 10LB10C & 0.2 & 97.7 & 0.06 & $<0.05$ & 0.6 & 0.062 & 0.15 & 0.4 & 42 & 0.2 & 2.8 & 49 & 11.6 & 0.001 \\
\hline $10 \mathrm{LB} 11 \mathrm{C}$ & 0.3 & 115.5 & 0.08 & $<0.05$ & 0.9 & 0.076 & 0.17 & 0.5 & 40 & 0.3 & 3.9 & 47 & 16.3 & 0.001 \\
\hline $10 \mathrm{LB} 12 \mathrm{C}$ & 0.3 & 102 & 0.08 & $<0.05$ & 0.9 & 0.08 & 0.16 & 0.4 & 44 & 0.3 & 3.9 & 49 & 15.5 & $<0.001$ \\
\hline
\end{tabular}


Table 3. Mercury and monomethylmercury concentrations in waters and sediment.

\begin{tabular}{|c|c|c|c|c|c|c|c|c|}
\hline Sample & Date & $\begin{array}{c}\text { Water } \\
\text { Hg Total } \\
\text { ng/L }\end{array}$ & $\begin{array}{c}\text { Water } \\
\text { Hg Filtered } \\
\text { ng/L }\end{array}$ & $\begin{array}{c}\text { Water } \\
\text { Total MMeHg } \\
\text { ng/L }\end{array}$ & $\begin{array}{c}\text { Sediment } \\
\mathrm{Hg} \\
\mathrm{ng} / \mathrm{g}\end{array}$ & $\begin{array}{c}\text { D.O.C. } \\
\text { mg/L }\end{array}$ & $\begin{array}{c}\text { Sediment } \\
\mathrm{MMeHg} \\
\mathrm{ng} / \mathrm{g}\end{array}$ & $\begin{array}{c}\% \mathrm{MMeHg} \\
\text { (MMeHg/Hg) } \\
\text { in sediment }\end{array}$ \\
\hline & \multicolumn{8}{|c|}{ WF Las Tablas Creek } \\
\hline 10LB1A & $4 / 6 / 10$ & 96.2 & 67.6 & 0.058 & 304,000 & 2.7 & 0.304 & 0.000001 \\
\hline 10LB4A & $4 / 6 / 10$ & 5.58 & & 0.055 & 44,900 & 2.6 & 0.096 & $2.13808 \mathrm{E}-06$ \\
\hline \multirow[t]{2}{*}{ 10LB4A2 } & $4 / 6 / 10$ & 5.91 & & & & & & \\
\hline & \multicolumn{8}{|c|}{ Mine Drainage from Adit } \\
\hline \multirow[t]{2}{*}{$10 \mathrm{LB} 2 \mathrm{~A}$} & $4 / 6 / 10$ & 46.7 & 13.5 & 0.02 & 72,400 & & 0.151 & $2.08564 \mathrm{E}-06$ \\
\hline & \multicolumn{8}{|c|}{ Reservoir Creek } \\
\hline 10LB3A & $4 / 6 / 10$ & 17.4 & & 0.101 & 228 & 6.6 & 0.042 & $1.84211 \mathrm{E}-04$ \\
\hline 10LB3A2 & $4 / 6 / 10$ & 17 & & & & & & \\
\hline
\end{tabular}


Table 4. Geochemistry of filtered samples from the Little Bonanza Mine, ICP-MS results (major elements, ICP-AES results).

\begin{tabular}{|c|c|c|c|c|c|c|c|c|c|c|c|c|c|c|c|c|}
\hline Sample & $\begin{array}{l}\text { Latitude } \\
\text { WF Las Ts }\end{array}$ & $\begin{array}{l}\text { Longitude } \\
\text { ablas Creek }\end{array}$ & $\begin{array}{c}\mathrm{Ag} \\
\mu \mathrm{g} / \mathrm{L}\end{array}$ & $\begin{array}{c}\mathrm{Al} \\
\mu \mathrm{g} / \mathrm{L}\end{array}$ & $\begin{array}{c}\text { As } \\
\mu \mathrm{g} / \mathrm{L}\end{array}$ & $\begin{array}{c}\text { B } \\
\mu g / L\end{array}$ & $\begin{array}{c}\mathrm{Ba} \\
\mu \mathrm{g} / \mathrm{L}\end{array}$ & $\begin{array}{c}\mathrm{Be} \\
\mu \mathrm{g} / \mathrm{L}\end{array}$ & $\begin{array}{c}\mathrm{Bi} \\
\mu \mathrm{g} / \mathrm{L}\end{array}$ & $\begin{array}{c}\mathrm{Ca} \\
\mathrm{mg} / \mathrm{L}\end{array}$ & $\begin{array}{c}\mathrm{Cd} \\
\mu \mathrm{g} / \mathrm{L}\end{array}$ & $\begin{array}{c}\mathrm{Ce} \\
\mu \mathrm{g} / \mathrm{L}\end{array}$ & $\begin{array}{c}\text { Co } \\
\mu \mathrm{g} / \mathrm{L}\end{array}$ & $\begin{array}{c}\mathrm{Cr} \\
\mu \mathrm{g} / \mathrm{L}\end{array}$ & $\begin{array}{c}\text { Cs } \\
\mu g / L\end{array}$ & $\begin{array}{c}\mathrm{Cu} \\
\mu \mathrm{g} / \mathrm{L}\end{array}$ \\
\hline 10LB1B & 35.58414 & -120.91121 & 1 & 5 & 1 & 123 & 124 & 0.05 & 0.2 & 35.2 & 0.02 & 0.03 & 0.02 & 1.6 & 0.02 & 1 \\
\hline 10LB4B & $\begin{array}{l}35.59845 \\
\text { Mine Drai }\end{array}$ & $\begin{array}{l}-120.91093 \\
\text { nage from } \mathrm{Ac}\end{array}$ & $\begin{array}{r}1 \\
\text { lit }\end{array}$ & 11.2 & 1 & 66.8 & 93.5 & 0.9 & 0.2 & 47.1 & 0.02 & 0.04 & 0.02 & 1 & 0.02 & 0.83 \\
\hline 10LB2B & $\begin{array}{l}35.583 \\
\text { Reservoir }\end{array}$ & $\begin{array}{l}\text {-120.91109 } \\
\text { Creek }\end{array}$ & 1 & 2.3 & 1 & 249 & 119 & 0.05 & 0.2 & 30.1 & 0.02 & 0.01 & 4.78 & 1.4 & 1.58 & 1.5 \\
\hline 10LB3B & 35.58424 & -120.90997 & 1 & 44.9 & 1 & 43.2 & 76.2 & 0.05 & 0.2 & 28.9 & 0.02 & 0.15 & 0.06 & 1.3 & 0.02 & 1.6 \\
\hline Sample & $\begin{array}{l}\text { Latitude } \\
\text { WF Las Ts }\end{array}$ & $\begin{array}{l}\text { Longitude } \\
\text { ablas Creek }\end{array}$ & $\begin{array}{c}\text { Dy } \\
\mu g / L\end{array}$ & $\begin{array}{c}\mathrm{Er} \\
\mu \mathrm{g} / \mathrm{L}\end{array}$ & $\begin{array}{c}\mathrm{Eu} \\
\mu \mathrm{g} / \mathrm{L}\end{array}$ & $\begin{array}{c}\mathrm{Fe} \\
\mu \mathrm{g} / \mathrm{L}\end{array}$ & $\begin{array}{c}\mathrm{Ga} \\
\mu \mathrm{g} / \mathrm{L}\end{array}$ & $\begin{array}{c}\text { Gd } \\
\mu g / L\end{array}$ & $\begin{array}{c}\mathrm{Ge} \\
\mu \mathrm{g} / \mathrm{L}\end{array}$ & $\begin{array}{l}\text { Ho } \\
\mu g / L\end{array}$ & $\underset{\mathrm{mg} / \mathrm{L}}{\mathrm{K}}$ & $\begin{array}{c}\mathrm{La} \\
\mu \mathrm{g} / \mathrm{L}\end{array}$ & $\underset{\mu \mathrm{Li} / \mathrm{L}}{\mathrm{Li}}$ & $\begin{array}{c}\mathrm{Lu} \\
\mu \mathrm{g} / \mathrm{L}\end{array}$ & $\underset{\mathrm{mg} / \mathrm{L}}{\mathrm{Mg}}$ & $\begin{array}{c}\mathrm{Mn} \\
\mu \mathrm{g} / \mathrm{L}\end{array}$ \\
\hline 10LB1B & 35.58414 & -120.91121 & 0.005 & 0.005 & 0.01 & 50 & 0.05 & 0.007 & 0.05 & 0.005 & 1.16 & 0.02 & 16.2 & 0.1 & 70.7 & 0.3 \\
\hline 10LB4B & $\begin{array}{l}35.59845 \\
\text { Mine Drai }\end{array}$ & $\begin{array}{l}-120.91093 \\
\text { nage from } \mathrm{Ac}\end{array}$ & $\begin{array}{l}0.02 \\
\text { lit }\end{array}$ & 0.005 & 0.005 & 50 & 0.05 & 0.02 & 0.05 & 0.005 & 0.7 & 0.05 & 2.8 & 0.1 & 20.1 & 1 \\
\hline 10LB2B & $\begin{array}{l}35.583 \\
\text { Reservoir }\end{array}$ & $\begin{array}{l}-120.91109 \\
\text { Creek }\end{array}$ & 0.005 & 0.005 & 0.009 & 50 & 0.05 & 0.005 & 0.1 & 0.005 & 1.94 & 0.01 & 48.5 & 0.1 & 129 & 2.4 \\
\hline 10LB3B & 35.58424 & -120.90997 & 0.05 & 0.03 & 0.02 & 86 & 0.05 & 0.06 & 0.05 & 0.01 & 0.82 & 0.13 & 0.9 & 0.1 & 14.7 & 2 \\
\hline Sample & $\begin{array}{l}\text { Latitude } \\
\text { WF Las Ts }\end{array}$ & $\begin{array}{l}\text { Longitude } \\
\text { ablas Creek }\end{array}$ & $\begin{array}{c}\text { Mo } \\
\mu g / L\end{array}$ & $\begin{array}{c}\mathrm{Na} \\
\mathrm{mg} / \mathrm{L}\end{array}$ & $\begin{array}{c}\mathrm{Nb} \\
\mu \mathrm{g} / \mathrm{L}\end{array}$ & $\begin{array}{c}\mathrm{Nd} \\
\mu \mathrm{g} / \mathrm{L}\end{array}$ & $\begin{array}{c}\mathrm{Ni} \\
\mu \mathrm{g} / \mathrm{L}\end{array}$ & $\begin{array}{c}P \\
\mathrm{mg} / \mathrm{L}\end{array}$ & $\begin{array}{c}\mathrm{Pb} \\
\mu \mathrm{g} / \mathrm{L}\end{array}$ & $\begin{array}{c}\mathrm{Pr} \\
\mu \mathrm{g} / \mathrm{L}\end{array}$ & $\begin{array}{c}\mathrm{Rb} \\
\mu \mathrm{g} / \mathrm{L}\end{array}$ & $\begin{array}{c}S b \\
\mu g / L\end{array}$ & $\begin{array}{c}\text { Sc } \\
\mu g / L\end{array}$ & $\begin{array}{c}\text { Se } \\
\mu g / L\end{array}$ & $\begin{array}{l}\mathrm{SiO} 2 \\
\mathrm{mg} / \mathrm{L}\end{array}$ & $\begin{array}{l}\mathrm{Sm} \\
\mu \mathrm{g} / \mathrm{L}\end{array}$ \\
\hline 10LB1B & 35.58414 & -120.91121 & 2 & 15 & 0.2 & 0.03 & 5 & 0.01 & 0.05 & 0.01 & 0.41 & 0.3 & 0.8 & 1 & 9.5 & 0.01 \\
\hline 10LB4B & $\begin{array}{l}35.59845 \\
\text { Mine Drai }\end{array}$ & $\begin{array}{l}-120.91093 \\
\text { nage from Ac }\end{array}$ & $\begin{array}{l}3.1 \\
\text { lit }\end{array}$ & 12.4 & 0.2 & 0.07 & 0.4 & 0.01 & 0.05 & 0.02 & 0.17 & 0.3 & 0.9 & 1 & 9.5 & 0.01 \\
\hline 10LB2B & $\begin{array}{l}35.583 \\
\text { Reservoir }\end{array}$ & $\begin{array}{l}-120.91109 \\
\text { Creek }\end{array}$ & 2 & 17.8 & 0.2 & 0.01 & 476 & 0.01 & 0.05 & 0.01 & 3.49 & 0.44 & 0.7 & 1 & 7.8 & 0.01 \\
\hline 10LB3B & 35.58424 & -120.90997 & 2 & 8.9 & 0.2 & 0.18 & 1.4 & 0.01 & 0.05 & 0.04 & 0.13 & 0.3 & 0.9 & 1 & 10.1 & 0.04 \\
\hline
\end{tabular}


Table 4 (cont'd)

\begin{tabular}{|c|c|c|c|c|c|c|c|c|c|c|c|c|c|c|c|c|}
\hline Sample & $\begin{array}{l}\text { Latitude } \\
\text { WF Las Ta }\end{array}$ & $\begin{array}{l}\text { Longitude } \\
\text { las Creek }\end{array}$ & $\begin{array}{l}\text { sO4 } \\
\mathrm{mg} / \mathrm{L}\end{array}$ & $\begin{array}{c}\mathrm{Sr} \\
\mu \mathrm{g} / \mathrm{L}\end{array}$ & $\begin{array}{c}\mathrm{Ta} \\
\mu \mathrm{g} / \mathrm{L}\end{array}$ & $\begin{array}{c}\mathrm{Tb} \\
\mu \mathrm{g} / \mathrm{L}\end{array}$ & $\begin{array}{c}\text { Th } \\
\mu g / L\end{array}$ & $\begin{array}{c}\mathrm{Ti} \\
\mu \mathrm{g} / \mathrm{L}\end{array}$ & $\begin{array}{c}\mathrm{TI} \\
\mu \mathrm{g} / \mathrm{L}\end{array}$ & $\begin{array}{c}\mathrm{Tm} \\
\mu \mathrm{g} / \mathrm{L}\end{array}$ & $\underset{\mu g / L}{U}$ & $\begin{array}{c}V \\
\mu g / L\end{array}$ & $\begin{array}{c}W \\
\mu g / L\end{array}$ & $\begin{array}{c}Y \\
\mu g / L\end{array}$ & $\begin{array}{c}Y b \\
\mu g / L\end{array}$ & $\begin{array}{c}\mathrm{Zn} \\
\mu \mathrm{g} / \mathrm{L}\end{array}$ \\
\hline 10LB1B & 35.58414 & -120.91121 & 28 & 274 & 0.05 & 0.005 & 0.2 & 0.6 & 0.1 & 0.005 & 0.16 & 0.6 & 0.5 & 0.08 & 0.006 & 1.7 \\
\hline \multirow[t]{2}{*}{ 10LB4B } & 35.59845 & -120.91093 & 43 & 298 & 0.02 & 0.005 & 0.2 & 3.4 & 0.1 & 0.005 & 0.37 & 0.5 & 0.5 & 0.09 & 0.006 & 0.7 \\
\hline & \multicolumn{16}{|c|}{ Mine Drainage from Adit } \\
\hline \multirow[t]{2}{*}{ 10LB2B } & 35.583 & -120.91109 & 130 & 460 & 0.05 & 0.005 & 0.2 & 2 & 0.1 & 0.005 & 0.14 & 0.6 & 0.5 & 0.03 & 0.005 & 1.7 \\
\hline & \multicolumn{16}{|c|}{ Reservoir Creek } \\
\hline 10LB3B & 35.58424 & -120.90997 & 17 & 209 & 0.05 & 0.008 & 0.2 & 10 & 0.1 & 0.005 & 0.14 & 0.8 & 0.5 & 0.28 & 0.03 & 0.5 \\
\hline \multirow[t]{2}{*}{ Sample } & Latitude & Longitude & $\begin{array}{c}\mathrm{Zr} \\
\mu \mathrm{g} / \mathrm{L}\end{array}$ & & & & & & & & & & & & & \\
\hline & \multicolumn{16}{|c|}{ WF Las Tablas Creek } \\
\hline 10LB1B & 35.58414 & -120.91121 & 0.2 & & & & & & & & & & & & & \\
\hline \multirow[t]{2}{*}{ 10LB4B } & 35.59845 & -120.91093 & 0.2 & & & & & & & & & & & & & \\
\hline & \multicolumn{16}{|c|}{ Mine Drainage from Adit } \\
\hline \multirow[t]{2}{*}{ 10LB2B } & 35.583 & -120.91109 & 0.2 & & & & & & & & & & & & & \\
\hline & \multicolumn{16}{|c|}{ Reservoir Creek } \\
\hline 10LB3B & 35.58424 & -120.90997 & 0.2 & & & & & & & & & & & & & \\
\hline
\end{tabular}


Table 5. Geochemistry of unfiltered samples from the Little Bonanza Mine, ICP-MS results (major elements, ICP-AES results).

\begin{tabular}{|c|c|c|c|c|c|c|c|c|c|c|c|c|c|c|c|c|}
\hline Sample & $\begin{array}{c}\text { Latitude } \\
\text { WF Las Tablas C }\end{array}$ & $\begin{array}{l}\text { Longitude } \\
\text { eek }\end{array}$ & $\begin{array}{c}\mathrm{Ag} \\
\mu \mathrm{g} / \mathrm{L}\end{array}$ & $\begin{array}{c}\text { Al } \\
\mu \mathrm{g} / \mathrm{L}\end{array}$ & $\begin{array}{c}\text { As } \\
\mu \mathrm{g} / \mathrm{L}\end{array}$ & $\begin{array}{c}\text { B } \\
\mu g / L\end{array}$ & $\begin{array}{c}\mathrm{Ba} \\
\mu \mathrm{g} / \mathrm{L}\end{array}$ & $\begin{array}{c}\mathrm{Be} \\
\mu \mathrm{g} / \mathrm{L}\end{array}$ & $\begin{array}{c}\mathrm{Bi} \\
\mu \mathrm{g} / \mathrm{L}\end{array}$ & $\begin{array}{c}\mathrm{Ca} \\
\mathrm{mg} / \mathrm{L}\end{array}$ & $\begin{array}{c}\mathrm{Cd} \\
\mu \mathrm{g} / \mathrm{L}\end{array}$ & $\begin{array}{c}\mathrm{Ce} \\
\mu \mathrm{g} / \mathrm{L}\end{array}$ & $\begin{array}{c}\text { Co } \\
\mu \mathrm{g} / \mathrm{L}\end{array}$ & $\begin{array}{c}\mathrm{Cr} \\
\mu \mathrm{g} / \mathrm{L}\end{array}$ & $\begin{array}{c}\text { Cs } \\
\mu \mathrm{g} / \mathrm{L}\end{array}$ & $\begin{array}{c}\mathrm{Cu} \\
\mu \mathrm{g} / \mathrm{L}\end{array}$ \\
\hline 10LB1B & 35.58414 & -120.91121 & 1 & 22.7 & 1 & 127 & 127 & 0.05 & 0.2 & 36.9 & 0.02 & 0.04 & 0.02 & 2.2 & 0.02 & 1.1 \\
\hline 10LB4B & 35.59845 & -120.91093 & 1 & 107 & 1 & 67.7 & 72.7 & 0.05 & 0.2 & 47.2 & 0.02 & 0.1 & 0.04 & 1 & 0.02 & 1.2 \\
\hline 10LB2B & $\begin{array}{l}\text { Mine Drainage fr } \\
35.583 \\
\text { Reservoir Creek }\end{array}$ & $\begin{array}{l}\text { m Adit } \\
-120.91109\end{array}$ & 1 & 5.9 & 1 & 246 & 116 & 0.05 & 0.2 & 29.3 & 0.02 & 0.01 & 4.67 & 1.1 & 1.53 & 1.5 \\
\hline 10LB3B & 35.58424 & -120.90997 & 1 & 794 & 1 & 45.5 & 88.6 & 0.05 & 0.2 & 30.3 & 0.02 & 0.84 & 0.7 & 5.9 & 0.04 & 2.7 \\
\hline Sample & $\begin{array}{c}\text { Latitude } \\
\text { WF Las Tablas C }\end{array}$ & $\begin{array}{l}\text { Longitude } \\
\text { eek }\end{array}$ & $\begin{array}{c}\text { Dy } \\
\mu g / L\end{array}$ & $\begin{array}{c}\text { Er } \\
\mu g / L\end{array}$ & $\begin{array}{c}\mathrm{Eu} \\
\mu \mathrm{g} / \mathrm{L}\end{array}$ & $\begin{array}{c}\mathrm{Fe} \\
\mu \mathrm{g} / \mathrm{L}\end{array}$ & $\begin{array}{c}\mathrm{Ga} \\
\mu \mathrm{g} / \mathrm{L}\end{array}$ & $\begin{array}{c}G d \\
\mu g / L\end{array}$ & $\begin{array}{c}\mathrm{Ge} \\
\mu \mathrm{g} / \mathrm{L}\end{array}$ & $\begin{array}{l}\mathrm{Ho} \\
\mu \mathrm{g} / \mathrm{L}\end{array}$ & $\begin{array}{c}\mathrm{K} \\
\mathrm{mg} / \mathrm{L}\end{array}$ & $\begin{array}{l}\mathrm{La} \\
\mu \mathrm{g} / \mathrm{L}\end{array}$ & $\underset{\mu g / L}{\mathrm{Li}}$ & $\begin{array}{c}\mathrm{Lu} \\
\mu \mathrm{g} / \mathrm{L}\end{array}$ & $\underset{\mathrm{mg} / \mathrm{L}}{\mathrm{Mg}}$ & $\underset{\mu g / L}{M n}$ \\
\hline 10LB1B & 35.58414 & -120.91121 & 0.01 & 0.007 & 0.01 & 50 & 0.05 & 0.008 & 0.05 & 0.005 & 1.19 & 0.02 & 14.7 & 0.1 & 71.9 & 0.8 \\
\hline 10LB4B & $\begin{array}{l}35.59845 \\
\text { Mine Drainage fr }\end{array}$ & $\begin{array}{l}-120.91093 \\
\text { m Adit }\end{array}$ & 0.02 & 0.01 & 0.007 & 112 & 0.05 & 0.03 & 0.05 & 0.005 & 0.85 & 0.06 & 8.9 & 0.1 & 20.2 & 3.2 \\
\hline 10LB2B & $\begin{array}{l}35.583 \\
\text { Reservoir Creek }\end{array}$ & -120.91109 & 0.005 & 0.005 & 0.008 & 50 & 0.05 & 0.005 & 0.1 & 0.005 & 1.96 & 0.01 & 45.1 & 0.1 & 128 & 2.5 \\
\hline 10LB3B & 35.58424 & -120.90997 & 0.099 & 0.061 & 0.03 & 912 & 0.26 & 0.13 & 0.05 & 0.02 & 0.91 & 0.35 & 3.6 & 0.1 & 15.5 & 21.7 \\
\hline Sample & $\begin{array}{c}\text { Latitude } \\
\text { WF Las Tablas C }\end{array}$ & Longitude & $\begin{array}{l}\text { Mo } \\
\mu g / L\end{array}$ & $\begin{array}{c}\mathrm{Na} \\
\mathrm{mg} / \mathrm{L}\end{array}$ & $\begin{array}{c}\mathrm{Nb} \\
\mu \mathrm{g} / \mathrm{L}\end{array}$ & $\begin{array}{c}\mathrm{Nd} \\
\mu \mathrm{g} / \mathrm{L}\end{array}$ & $\underset{\mu \mathrm{gi} / \mathrm{L}}{\mathrm{Ni}}$ & $\begin{array}{c}P \\
\mathrm{mg} / \mathrm{L}\end{array}$ & $\begin{array}{c}\mathrm{Pb} \\
\mu \mathrm{g} / \mathrm{L}\end{array}$ & $\begin{array}{c}\mathrm{Pr} \\
\mu \mathrm{g} / \mathrm{L}\end{array}$ & $\begin{array}{c}\mathrm{Rb} \\
\mu \mathrm{g} / \mathrm{L}\end{array}$ & $\begin{array}{c}\mathrm{Sb} \\
\mu \mathrm{g} / \mathrm{L}\end{array}$ & $\begin{array}{c}\mathrm{Sc} \\
\mu \mathrm{g} / \mathrm{L}\end{array}$ & $\begin{array}{c}\text { Se } \\
\mu \mathrm{g} / \mathrm{L}\end{array}$ & $\begin{array}{l}\mathrm{SiO} 2 \\
\mathrm{mg} / \mathrm{L}\end{array}$ & $\underset{\mu \mathrm{g} / \mathrm{L}}{\mathrm{Sm}}$ \\
\hline 10LB1B & 35.58414 & -120.91121 & 2 & 15.2 & 0.2 & 0.03 & 5.4 & 0.01 & 0.05 & 0.01 & 0.42 & 0.3 & 0.9 & 1 & 10.1 & 0.01 \\
\hline 10LB4B & $\begin{array}{l}35.59845 \\
\text { Mine Drainage fr }\end{array}$ & $\begin{array}{l}-120.91093 \\
\text { m Adit }\end{array}$ & 2 & 17.6 & 0.2 & 0.08 & 0.4 & 0.01 & 0.08 & 0.02 & 0.24 & 0.3 & 1.4 & 1 & 16 & 0.01 \\
\hline 10LB2B & $\begin{array}{l}35.583 \\
\text { Reservoir Creek }\end{array}$ & -120.91109 & 2 & 18.6 & 0.2 & 0.01 & 457 & 0.01 & 0.05 & 0.01 & 3.27 & 0.44 & 0.7 & 1 & 7.8 & 0.01 \\
\hline 10LB3B & 35.58424 & -120.90997 & 2 & 9.16 & 0.2 & 0.44 & 9.6 & 0.01 & 0.3 & 0.1 & 0.54 & 0.3 & 1.4 & 1 & 14 & 0.1 \\
\hline
\end{tabular}




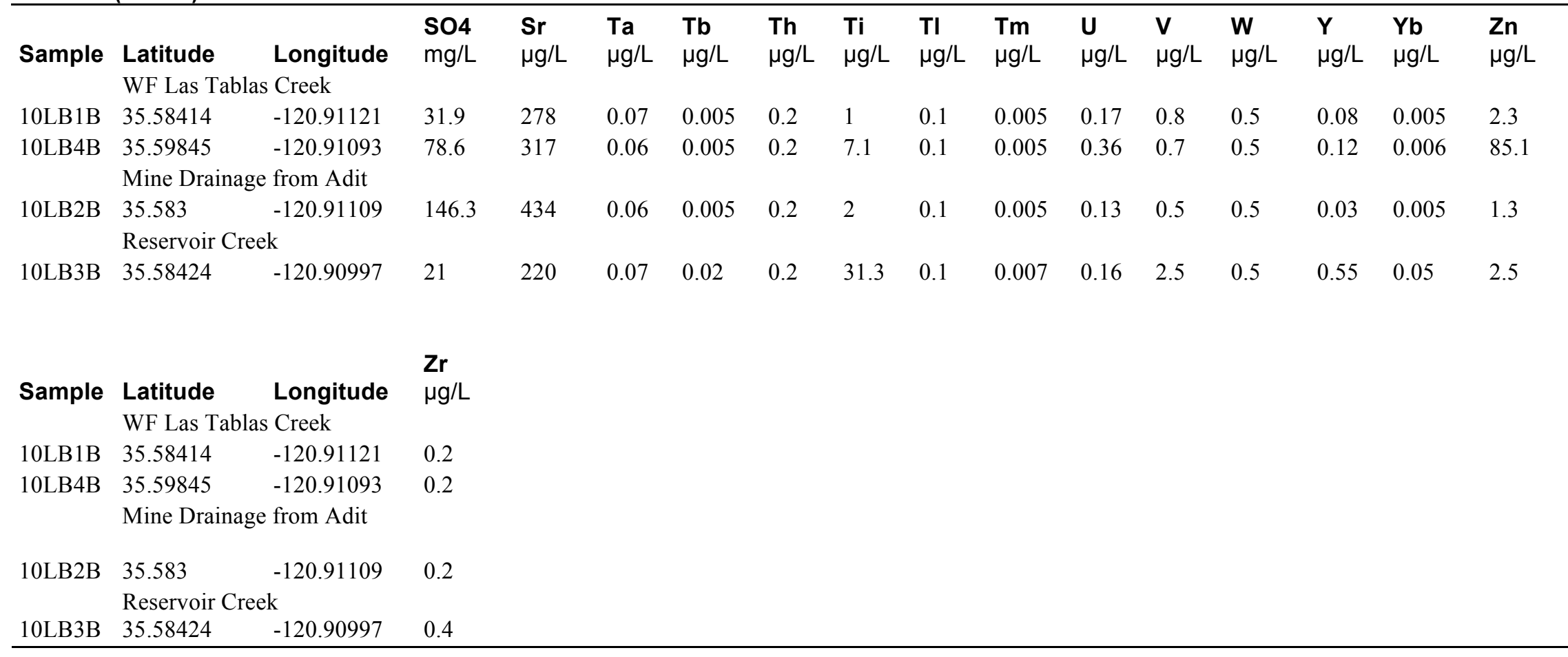


Table 6. Invertebrate samples collected from the Little Bonanza Mine and Trout Creek on April 6, 2010.

\begin{tabular}{|c|c|c|c|c|c|c|c|c|c|c|c|}
\hline Sample code & Site & Location & Order & Family & No. & Mass (g) & Ave. Mass (g) & $\%$ Solids & $\begin{array}{c}\mathrm{Hg}_{\mathrm{T}} \\
(\mu \mathrm{g} / \mathrm{g} w w) \\
\end{array}$ & $\begin{array}{c}\text { MeHg } \\
(\mu g / g \text { ww) } \\
\end{array}$ & $\% \mathrm{MeHg}$ \\
\hline $\begin{array}{l}\text { CR-LBUP- } \\
040610-001\end{array}$ & LEBU & $\begin{array}{l}\text { Little Bonanza } \\
\text { Upstream }\end{array}$ & Megaloptera & Corydalidae & 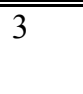 & 1.47 & 0.490 & 20.54 & 0.432 & 0.085 & 19.61 \\
\hline $\begin{array}{l}\text { CR-LBUP- } \\
040610-002\end{array}$ & LBUP & $\begin{array}{l}\text { Little Bonanza } \\
\text { Upstream }\end{array}$ & Megaloptera & Corydalidae & 6 & 0.53 & 0.088 & NA & 0.446 & 0.074 & 16.61 \\
\hline $\begin{array}{l}\text { CR-LBBR- } \\
040610-001\end{array}$ & LBBR & $\begin{array}{l}\text { Little Bonanza } \\
\text { at Bridge }\end{array}$ & Megaloptera & Corydalidae & 3 & 1.08 & 0.360 & NA & 0.136 & 0.057 & 41.99 \\
\hline $\begin{array}{l}\text { CR-LBBR- } \\
040610-003\end{array}$ & LBBR & $\begin{array}{l}\text { Little Bonanza } \\
\text { at Bridge }\end{array}$ & Odonata & Aeshnidae & 6 & 1.34 & 0.223 & 22.74 & 0.118 & 0.092 & 77.54 \\
\hline $\begin{array}{l}\text { CR-LBBR- } \\
040610-002\end{array}$ & LBBR & $\begin{array}{l}\text { Little Bonanza } \\
\text { at Bridge }\end{array}$ & Odonata & Gomphidae & 5 & 1.03 & 0.206 & 29.58 & 0.198 & 0.148 & 74.75 \\
\hline $\begin{array}{l}\text { CR-LBBR- } \\
040610-004\end{array}$ & LBBR & $\begin{array}{l}\text { Little Bonanza } \\
\text { at Bridge }\end{array}$ & Coleoptera & Dytiscidae & 7 & 0.53 & 0.076 & NA & 0.129 & 0.090 & 69.61 \\
\hline $\begin{array}{l}\text { CR-LBBR- } \\
040610-005\end{array}$ & LBBR & $\begin{array}{l}\text { Little Bonanza } \\
\text { at Bridge }\end{array}$ & Hemiptera & Gerridae & 15 & 0.91 & 0.061 & 37.71 & 0.127 & 0.084 & 66.46 \\
\hline $\begin{array}{l}\text { CR-TRCR- } \\
040610-002\end{array}$ & TRCR & Trout Creek & Odonata & Aeshnidae & 3 & 1.59 & 0.530 & 15.03 & 0.042 & 0.037 & 86.52 \\
\hline $\begin{array}{l}\text { CR-TRCR- } \\
040610-003\end{array}$ & TRCR & Trout Creek & Odonata & Libellulidae & 10 & 2.12 & 0.212 & 18.43 & 0.039 & 0.035 & 90.18 \\
\hline $\begin{array}{l}\text { CR-TRCR- } \\
040610-004\end{array}$ & TRCR & Trout Creek & Odonata & Libellulidae & 10 & 2.04 & 0.204 & 17.64 & 0.040 & 0.039 & 96.51 \\
\hline $\begin{array}{l}\text { CR-TRCR- } \\
040610-006\end{array}$ & TRCR & Trout Creek & Odonata & Coenagrionidae & 20 & 1.10 & 0.055 & 25.09 & 0.016 & 0.013 & 86.45 \\
\hline $\begin{array}{l}\text { CR-TRCR- } \\
040610-001\end{array}$ & TRCR & Trout Creek & Coleoptera & Dytiscidae & 13 & 0.79 & 0.061 & 35.85 & 0.037 & 0.034 & 93.19 \\
\hline $\begin{array}{l}\text { CR-TRCR- } \\
040610-005\end{array}$ & TRCR & Trout Creek & Hemiptera & Gerridae & 14 & 0.67 & 0.048 & NA & 0.016 & 0.014 & 89.10 \\
\hline
\end{tabular}

$\mathrm{NA}=$ not analyzed 
Table 7. Sample sites and physical and selected chemical parameters for waters from the Little Bonanza Mine collected during a high-flow sampling event.

\begin{tabular}{|c|c|c|c|c|c|c|c|c|}
\hline $\begin{array}{c}\text { Field } \\
\text { Number }\end{array}$ & Latitude & Longitude & $\begin{array}{l}\text { Sampling } \\
\text { Date }\end{array}$ & Sample Site Description & $\begin{array}{c}\text { Conductivity } \\
\text { micro Siemens }\end{array}$ & $\mathrm{pH}$ & $\begin{array}{c}\text { Temperature } \\
{ }^{\circ} \mathrm{C}\end{array}$ & $\begin{array}{c}\text { Dissolved } \mathrm{O}_{2} \\
\text { ppm }\end{array}$ \\
\hline & \multicolumn{8}{|c|}{ "WF Las Tablas Creek } \\
\hline 11LB1A & 35.58414 & -120.91121 & $2 / 21 / 11$ & Little Bonanza Creek & 189 & 7.27 & 11.5 & 5 \\
\hline $11 \mathrm{LB} 4 \mathrm{~A}$ & 35.59845 & -120.91093 & $2 / 21 / 11$ & Tablas Creek, $1.25 \mathrm{~km}$ downstream from mine & 150.3 & 7.52 & 12.55 & 4.6 \\
\hline 11LB5A & 35.59845 & -120.91093 & $2 / 21 / 11$ & Tablas Creek, $2.25 \mathrm{~km}$ downstream from mine & 151 & 7.2 & 12.55 & 4.57 \\
\hline \multirow[t]{2}{*}{ 11LB2A } & 35.583 & -120.91109 & $2 / 21 / 11$ & Downstream from mine adit drainage & 101 & 7.16 & 12.4 & 4.7 \\
\hline & \multicolumn{8}{|c|}{ Reservoir Creek } \\
\hline 11LB3A & 35.58424 & -120.90997 & $2 / 21 / 11$ & Reservoir drainage & 199 & 7.39 & 12.55 & 5.03 \\
\hline
\end{tabular}


Table 8. Mercury and monomethylmercury concentrations in waters and sediment collected during a high-flow sampling event

\begin{tabular}{|c|c|c|c|c|c|}
\hline Sample & $\begin{array}{c}\text { Water } \\
\text { DOC } \\
\text { mg/L }\end{array}$ & $\begin{array}{c}\text { Water } \\
\text { Hg Total } \\
\text { ng/L }\end{array}$ & $\begin{array}{c}\text { Water } \\
\mathrm{Hg} \text { Filtered } \\
\text { ng/L }\end{array}$ & $\begin{array}{c}\text { Water } \\
\text { Total MMeHg } \\
\text { ng/L } \\
\end{array}$ & $\begin{array}{c}\text { Total Suspended } \\
\text { Sediment (TSS) } \\
\text { mg/L }\end{array}$ \\
\hline \multicolumn{6}{|c|}{ WF Las Tablas Creek } \\
\hline 11LB1A & 6.28 & 206 & 51.8 & 0.208 & 14.6 \\
\hline 11LB4A & 7.04 & 135 & 24.7 & 0.164 & 56.1 \\
\hline 11LB5A & 7.32 & 68.3 & 27.8 & 0.163 & 65.0 \\
\hline 11LB2A & 9.38 & 190 & 55 & 0.165 & 22.5 \\
\hline \multicolumn{6}{|c|}{ Reservoir Creek } \\
\hline $11 \mathrm{LB} 3 \mathrm{~A}$ & 6.09 & 49.1 & 36 & 0.236 & 40.5 \\
\hline
\end{tabular}


Table 9. Concentrations of anions and selected cations in filtered water from the Little Bonanza Mine collected during a high-flow sampling event

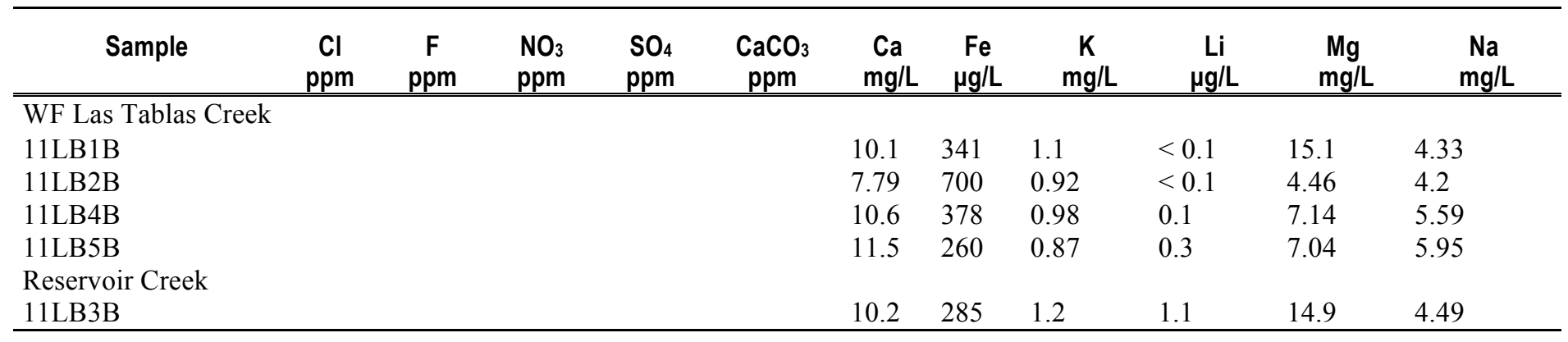


Table 10. Geochemistry of filtered samples from the Little Bonanza Mine collected during a high-flow sampling event, ICP-MS results (major elements, ICP-AES results)

\begin{tabular}{|c|c|c|c|c|c|c|c|c|c|c|c|c|c|c|c|c|c|c|c|}
\hline Sample & $\begin{array}{c}\mathrm{Al} \\
\mu \mathrm{g} / \mathrm{L} \\
\mathrm{WF} \mathrm{La}\end{array}$ & $\begin{array}{c}\text { B } \\
\mu \mathrm{g} / \mathrm{L} \\
\text { Tabla }\end{array}$ & $\begin{array}{c}\mathrm{Ba} \\
\mu \mathrm{g} / \mathrm{L} \\
\text { Creek }\end{array}$ & $\begin{array}{c}\mathrm{Ca} \\
\mathrm{mg} / \mathrm{L}\end{array}$ & $\begin{array}{c}\mathrm{Ce} \\
\mu \mathrm{g} / \mathrm{L}\end{array}$ & $\begin{array}{c}\text { Co } \\
\mu \mathrm{g} / \mathrm{L}\end{array}$ & $\begin{array}{c}\mathrm{Cr} \\
\mu \mathrm{g} / \mathrm{L}\end{array}$ & $\begin{array}{c}\text { Cs } \\
\mu \mathrm{g} / \mathrm{L}\end{array}$ & $\begin{array}{c}\mathrm{Cu} \\
\mu \mathrm{g} / \mathrm{L}\end{array}$ & $\begin{array}{c}\text { Dy } \\
\mu \mathrm{g} / \mathrm{L}\end{array}$ & $\begin{array}{c}\mathrm{Er} \\
\mu \mathrm{g} / \mathrm{L}\end{array}$ & $\begin{array}{c}\text { Eu } \\
\mu \mathrm{g} / \mathrm{L}\end{array}$ & $\begin{array}{c}\mathrm{Fe} \\
\mu \mathrm{g} / \mathrm{L}\end{array}$ & $\begin{array}{c}\mathrm{Ga} \\
\mu \mathrm{g} / \mathrm{L}\end{array}$ & $\begin{array}{l}\text { Gd/P } \\
\mu \mathrm{g} / \mathrm{L}\end{array}$ & $\begin{array}{c}\mathrm{Ho} \\
\mu \mathrm{g} / \mathrm{L}\end{array}$ & $\begin{array}{c}\mathrm{K} \\
\mathrm{mg} / \mathrm{L}\end{array}$ & $\begin{array}{c}\mathrm{La} \\
\mu \mathrm{g} / \mathrm{L}\end{array}$ & $\begin{array}{c}\mathrm{Li} \\
\mu \mathrm{g} / \mathrm{L}\end{array}$ \\
\hline 11LB1B & 274 & 38.7 & 36.1 & 10.1 & 0.27 & 0.71 & 3.3 & 0.04 & 1.7 & 0.063 & 0.03 & 0.02 & 341 & 0.1 & 0.062 & 0.01 & 1.1 & 0.14 & $<0.1$ \\
\hline 11LB2B & 630 & 25.7 & 33.9 & 7.79 & 1.3 & 1.5 & 4.8 & 0.05 & 2.4 & 0.17 & 0.098 & 0.052 & 700 & 0.23 & 0.22 & 0.04 & 0.92 & 0.59 & $<0.1$ \\
\hline 11LB4B & 348 & 35.9 & 29.9 & 10.6 & 0.53 & 2.4 & 3 & 0.03 & 1.6 & 0.1 & 0.053 & 0.01 & 378 & 0.1 & 0.11 & 0.01 & 0.98 & 0.27 & 0.1 \\
\hline 11LB5B & 244 & 34.2 & 29.4 & 11.5 & 0.44 & 0.44 & 2.2 & $\begin{array}{l}< \\
0.02\end{array}$ & 1.5 & 0.083 & 0.053 & 0.03 & 260 & 0.08 & 0.1 & 0.02 & 0.87 & 0.28 & 0.3 \\
\hline 11LB3B & $\begin{array}{l}\text { Reserv } \\
248\end{array}$ & $\begin{array}{c}\text { bir Cre } \\
39.4\end{array}$ & $\mathrm{k}$ & 10.2 & 0.26 & 1 & 3 & 0.04 & 1.4 & 0.058 & 0.04 & 0.02 & 285 & 0.07 & 0.056 & 0.01 & 1.2 & 0.14 & 1.1 \\
\hline Sample & $\begin{array}{c}\mathrm{Mg} \\
\mathrm{mg} / \mathrm{L} \\
\mathrm{WF} \text { La }\end{array}$ & $\begin{array}{c}\text { Mn } \\
\mu g / L \\
\text { Tabla }\end{array}$ & $\begin{array}{c}\mathrm{Na} \\
\mathrm{mg} / \mathrm{L} \\
\text { Creek }\end{array}$ & $\begin{array}{c}\mathrm{Nd} \\
\mu \mathrm{g} / \mathrm{L}\end{array}$ & $\begin{array}{c}\mathrm{Ni} \\
\mu \mathrm{g} / \mathrm{L}\end{array}$ & $\begin{array}{c}P \\
\mathrm{mg} / \mathrm{L}\end{array}$ & $\begin{array}{c}\mathrm{Pb} \\
\mu \mathrm{g} / \mathrm{L}\end{array}$ & $\begin{array}{c}\mathrm{Pr} \\
\mu \mathrm{g} / \mathrm{L}\end{array}$ & $\begin{array}{c}\mathrm{Rb} \\
\mu \mathrm{g} / \mathrm{L}\end{array}$ & $\begin{array}{c}\mathrm{Sc} \\
\mu \mathrm{g} / \mathrm{L}\end{array}$ & $\begin{array}{l}\mathrm{SiO}_{2} \\
\mathrm{mg} / \mathrm{L}\end{array}$ & $\begin{array}{c}\mathrm{Sm} \\
\mu \mathrm{g} / \mathrm{L}\end{array}$ & $\begin{array}{c}\mathrm{SO}_{4} \\
\mathrm{mg} / \mathrm{L}\end{array}$ & $\begin{array}{c}\mathrm{Sr} \\
\mu \mathrm{g} / \mathrm{L}\end{array}$ & $\begin{array}{l}\text { Tb/P } \\
\mu g / L\end{array}$ & $\begin{array}{c}\mathrm{Ti} \\
\mu \mathrm{g} / \mathrm{L}\end{array}$ & $\begin{array}{c}\mathrm{Tm} \\
\mu \mathrm{g} / \mathrm{L}\end{array}$ & $\begin{array}{c}V \\
\mu \mathrm{g} / \mathrm{L}\end{array}$ & \\
\hline 11LB1B & 15.1 & 9.6 & 4.33 & 0.23 & 8 & 0.02 & 0.16 & 0.05 & 0.46 & 1 & 7.11 & 0.05 & 8.8 & 73.1 & 0.01 & 2.9 & 0.006 & 1.2 & \\
\hline $11 \mathrm{LB} 2 \mathrm{~B}$ & 4.46 & 19 & 4.2 & 0.84 & 10.6 & 0.02 & 0.35 & 0.2 & 0.63 & 1.5 & 9.52 & 0.2 & 9.1 & 61.3 & 0.04 & 18.1 & 0.02 & 1.9 & \\
\hline 11LB4B & 7.14 & 12.2 & 5.59 & 0.37 & 6 & 0.03 & 0.16 & 0.08 & 0.44 & 1.3 & 9.16 & 0.08 & 15 & 89 & 0.01 & 14.5 & 0.007 & 1.5 & \\
\hline 11LB5B & $\begin{array}{l}7.04 \\
\text { Reserv }\end{array}$ & $\begin{array}{l}5.9 \\
\text { oir Cre }\end{array}$ & 5.95 & 0.43 & 5.1 & 0.02 & 0.12 & 0.1 & 0.27 & 1.2 & 9.51 & 0.08 & 16 & 90.9 & 0.02 & 6.8 & 0.005 & 1 & \\
\hline 11LB3B & 14.9 & 8.5 & 4.49 & 0.21 & 7.4 & 0.01 & 0.1 & 0.05 & 0.37 & 1 & 7.03 & 0.05 & 8.4 & 74.7 & 0.009 & 1.5 & 0.005 & 1 & \\
\hline Sample & $\begin{array}{c}Y \\
\mu g / L \\
\text { WF La }\end{array}$ & $\begin{array}{c}Y b \\
\mu g / L \\
\text { Tabla }\end{array}$ & $\begin{array}{c}Y \\
\mu g / L \\
\text { Creek }\end{array}$ & $\begin{array}{c}\mathrm{Yb} \\
\mu \mathrm{g} / \mathrm{L}\end{array}$ & $\begin{array}{c}\mathrm{Zn} \\
\mu \mathrm{g} / \mathrm{L}\end{array}$ & & & & & & & & & & & & & & \\
\hline 11LB1B & 0.32 & 0.03 & 0.08 & 0.006 & 1.7 & & & & & & & & & & & & & & \\
\hline 11LB2B & 0.94 & 0.08 & 0.03 & $<0.005$ & 1.7 & & & & & & & & & & & & & & \\
\hline 11LB4B & 0.45 & 0.04 & 0.09 & 0.006 & 0.7 & & & & & & & & & & & & & & \\
\hline 11LB5B & $\begin{array}{l}0.46 \\
\text { Reserv }\end{array}$ & $\begin{array}{l}0.04 \\
\text { oir Cre }\end{array}$ & & & & & & & & & & & & & & & & & \\
\hline 11LB3B & 0.29 & 0.02 & 0.28 & 0.03 & 0.5 & & & & & & & & & & & & & & \\
\hline
\end{tabular}

Not detected: Ag $<1 \mu \mathrm{g} / \mathrm{L}, \mathrm{As}<1 \mu \mathrm{g} / \mathrm{L}, \mathrm{Be}<0.05 \mu \mathrm{g} / \mathrm{L}, \mathrm{Bi}<0.2 \mu \mathrm{g} / \mathrm{L}, \mathrm{Cd}<0.02 \mu \mathrm{g} / \mathrm{L}, \mathrm{Mo}<2 \mu \mathrm{g} / \mathrm{L}$,

$\mathrm{Nb}<0.2 \mu \mathrm{g} / \mathrm{L}, \mathrm{Sb}<0.3 \mu \mathrm{g} / \mathrm{L}, \mathrm{Se}<1 \mu \mathrm{g} / \mathrm{L}, \mathrm{Ta}<0.02 \mu \mathrm{g} / \mathrm{L}, \mathrm{Th}<0.2 \mu \mathrm{g} / \mathrm{L}, \mathrm{Tl}<0.1 \mu \mathrm{g} / \mathrm{L}, \mathrm{U}<0.1 \mu \mathrm{g} / \mathrm{L}, \mathrm{W}<0.5 \mu \mathrm{g} / \mathrm{L}, \mathrm{Zn}<3 \mu \mathrm{g} / \mathrm{L}, \mathrm{Zr}<0.2 \mu \mathrm{g} / \mathrm{L}$ 
Table 11. Geochemistry of unfiltered samples from the Little Bonanza Mine collected during a high-flow sampling event, ICP-MS results

\begin{tabular}{|c|c|c|c|c|c|c|c|c|c|c|c|c|c|c|c|c|c|c|}
\hline Sample & $\begin{array}{c}\text { Al } \\
\mu \mathrm{g} / \mathrm{L} \\
\mathrm{WF} \text { La }\end{array}$ & $\begin{array}{c}\text { B } \\
\mu \mathrm{g} / \mathrm{L} \\
\mathrm{s} \text { Tabla }\end{array}$ & $\begin{array}{c}\mathrm{Ba} \\
\mu \mathrm{g} / \mathrm{L} \\
\text { Creek }\end{array}$ & $\begin{array}{c}\mathrm{Bi} \\
\mu \mathrm{g} / \mathrm{L}\end{array}$ & $\begin{array}{c}\mathrm{Ca} \\
\mathrm{mg} / \mathrm{L}\end{array}$ & $\begin{array}{c}\mathrm{Cd} \\
\mu \mathrm{g} / \mathrm{L}\end{array}$ & $\begin{array}{c}\mathrm{Ce} \\
\mu \mathrm{g} / \mathrm{L}\end{array}$ & $\begin{array}{c}\text { Co } \\
\mu \mathrm{g} / \mathrm{L}\end{array}$ & $\begin{array}{c}\mathrm{Cr} \\
\mu \mathrm{g} / \mathrm{L}\end{array}$ & $\begin{array}{c}\mathrm{Cs} \\
\mu \mathrm{g} / \mathrm{L}\end{array}$ & $\begin{array}{c}\mathrm{Cu} \\
\mu \mathrm{g} / \mathrm{L}\end{array}$ & $\begin{array}{c}\text { Dy } \\
\mu \mathrm{g} / \mathrm{L}\end{array}$ & $\begin{array}{c}\mathrm{Er} \\
\mu \mathrm{g} / \mathrm{L}\end{array}$ & $\begin{array}{c}\mathrm{Eu} \\
\mu \mathrm{g} / \mathrm{L}\end{array}$ & $\begin{array}{c}\mathrm{Fe} \\
\mu \mathrm{g} / \mathrm{L}\end{array}$ & $\begin{array}{c}\mathrm{Ga} \\
\mu \mathrm{g} / \mathrm{L}\end{array}$ & $\begin{array}{l}\text { Gd/P } \\
\mu g / L\end{array}$ & $\begin{array}{r}\mathrm{Ho} \\
\mu \mathrm{g} / \mathrm{L}\end{array}$ \\
\hline 11LB1A & 1,660 & 40.6 & 49 & 0.4 & 10.8 & 0.02 & 0.93 & 1.8 & 12.1 & 0.11 & 3.3 & 0.15 & 0.076 & 0.05 & 1,870 & 0.53 & 0.16 & 0.03 \\
\hline $11 \mathrm{LB} 2 \mathrm{~A}$ & 1,850 & 27.2 & 48 & $<0.2$ & 7.93 & $<0.02$ & 3 & 1.6 & 12 & 0.14 & 3.8 & 0.3 & 0.14 & 0.072 & 2,200 & 0.67 & 0.33 & 0.06 \\
\hline 11LB4A & 2,090 & 35.7 & 48.8 & $<0.2$ & 11.3 & $<0.02$ & 2.1 & 2.4 & 13.6 & 0.11 & 4.2 & 0.23 & 0.13 & 0.063 & 2,790 & 0.7 & 0.27 & 0.05 \\
\hline 11LB5A & \multicolumn{17}{|c|}{ Reservoir Creek } & 0.05 \\
\hline $11 \mathrm{LB} 3 \mathrm{~A}$ & 1,410 & 40.7 & 49.2 & $<0.2$ & 10.8 & $<0.02$ & 0.86 & 1.6 & 10.5 & 0.07 & 3.1 & 0.15 & 0.07 & 0.04 & 1,620 & 0.46 & 0.15 & 0.03 \\
\hline Sample & $\begin{array}{c}\mathrm{K} \\
\mathrm{mg} / \mathrm{L} \\
\mathrm{WF} \text { La }\end{array}$ & $\begin{array}{c}\text { La } \\
\mu \mathrm{g} / \mathrm{L} \\
\mathrm{s} \text { Tabla }\end{array}$ & $\begin{array}{c}\mathrm{Li} \\
\mu \mathrm{g} / \mathrm{L} \\
\text { Creek }\end{array}$ & $\begin{array}{c}\mathrm{Mg} \\
\mu \mathrm{g} / \mathrm{L}\end{array}$ & $\begin{array}{c}M n \\
\mu g / L\end{array}$ & $\begin{array}{c}\mathrm{Na} \\
\mathrm{mg} / \mathrm{L}\end{array}$ & $\begin{array}{c}\mathrm{Nb} \\
\mu \mathrm{g} / \mathrm{L}\end{array}$ & $\begin{array}{c}\mathrm{Nd} \\
\mu \mathrm{g} / \mathrm{L}\end{array}$ & $\underset{\mu \mathrm{g} / \mathrm{L}}{\mathrm{Ni}}$ & $\begin{array}{c}P \\
\mathrm{mg} / \mathrm{L}\end{array}$ & $\begin{array}{c}\mathrm{Pb} \\
\mu \mathrm{g} / \mathrm{L}\end{array}$ & $\begin{array}{c}\mathrm{Pr} \\
\mu \mathrm{g} / \mathrm{L}\end{array}$ & $\begin{array}{c}\mathrm{Rb} \\
\mu \mathrm{g} / \mathrm{L}\end{array}$ & $\begin{array}{c}S c \\
\mu \mathrm{g} / \mathrm{L}\end{array}$ & $\begin{array}{l}\mathrm{SiO}_{2} \\
\mathrm{mg} / \mathrm{L}\end{array}$ & $\begin{array}{c}\mathrm{Sm} \\
\mu \mathrm{g} / \mathrm{L}\end{array}$ & $\begin{array}{c}\mathrm{SO}_{4} \\
\mathrm{mg} / \mathrm{L}\end{array}$ & $\begin{array}{c}\mathrm{Sr} \\
\mu \mathrm{g} / \mathrm{L}\end{array}$ \\
\hline $11 \mathrm{LB} 1 \mathrm{~A}$ & 1.3 & 0.43 & 2.9 & 17.3 & 50.7 & 4.46 & 0.54 & 0.58 & 24.3 & 0.02 & 0.46 & 0.13 & 1.1 & 2 & 12.4 & 0.14 & 8.2 & 75.9 \\
\hline $11 \mathrm{LB} 2 \mathrm{~A}$ & 1.1 & 1 & 1.1 & 5.64 & 51.7 & 3.96 & 0.38 & 1.4 & 22 & 0.04 & 0.96 & 0.32 & 1.7 & 2.4 & 14.3 & 0.31 & 8 & 61.6 \\
\hline 11LB4A & 1.1 & 0.81 & 2.4 & 9.33 & 78.2 & 5.46 & $<0.2$ & 1.1 & 25.5 & 0.05 & 0.86 & 0.26 & 1.3 & 2.6 & 16.4 & 0.26 & 14 & 88.1 \\
\hline 11LB5A & 1 & 0.77 & 1.9 & 9.04 & 62.9 & 6.09 & $<0.2$ & 0.99 & 18.8 & 0.04 & 0.74 & 0.22 & 1.1 & 2.2 & 15 & 0.25 & 16 & 93.8 \\
\hline 11LB3A & $\begin{array}{l}\text { Reserv } \\
1.3\end{array}$ & $\begin{array}{c}\text { oir Cre } \\
0.4\end{array}$ & k 2.2 & 17.4 & 47.8 & 4.51 & $<0.2$ & 0.53 & 23.3 & 0.02 & 0.42 & 0.11 & 0.91 & 1.8 & 11.2 & 0.15 & 8.7 & 79 \\
\hline Sample & $\begin{array}{c}\mathrm{Ta} \\
\mu \mathrm{g} / \mathrm{L} \\
\text { WF La }\end{array}$ & $\begin{array}{l}\text { Tb/P } \\
\mu g / L \\
\text { S Tabla }\end{array}$ & $\begin{array}{c}\mathrm{Ti} \\
\mu \mathrm{g} / \mathrm{L} \\
\text { Creek }\end{array}$ & $\begin{array}{c}\mathrm{TI} \\
\mu \mathrm{g} / \mathrm{L}\end{array}$ & $\begin{array}{c}\mathrm{Tm} \\
\mu \mathrm{g} / \mathrm{L}\end{array}$ & $\begin{array}{c}U \\
\mu g / L\end{array}$ & $\begin{array}{c}V \\
\mu \mathrm{g} / \mathrm{L}\end{array}$ & $\begin{array}{c}Y \\
\mu \mathrm{g} / \mathrm{L}\end{array}$ & $\begin{array}{c}Y b \\
\mu g / L\end{array}$ & $\begin{array}{c}\mathrm{Zn} \\
\mu \mathrm{g} / \mathrm{L}\end{array}$ & $\begin{array}{c}Y \\
\mu g / L\end{array}$ & $\begin{array}{c}\mathrm{Yb} \\
\mu \mathrm{g} / \mathrm{L}\end{array}$ & $\begin{array}{c}\mathrm{Zn} \\
\mu \mathrm{g} / \mathrm{L}\end{array}$ & $\begin{array}{c}\mathrm{Zr} \\
\mu \mathrm{g} / \mathrm{L}\end{array}$ & & & & \\
\hline 11LB1A & 0.07 & 0.02 & 25.3 & 0.21 & 0.01 & $<0.1$ & 4.4 & 0.81 & 0.08 & 5.4 & 0.08 & 0.005 & 2.3 & $<0.2$ & & & & \\
\hline $11 \mathrm{LB} 2 \mathrm{~A}$ & 0.09 & 0.05 & 53.3 & $<0.1$ & 0.02 & $<0.1$ & 4.8 & 1.4 & 0.13 & 6.2 & 0.03 & $<0.005$ & 1.3 & $<0.2$ & & & & \\
\hline $11 \mathrm{LB} 4 \mathrm{~A}$ & 0.05 & 0.04 & 56.4 & $<0.1$ & 0.02 & $<0.1$ & 6 & 1.2 & 0.11 & 7.7 & 0.12 & 0.006 & 85.1 & $<0.2$ & & & & \\
\hline 11LB5A & 0.05 & 0.03 & 39 & $<0.1$ & 0.01 & 0.1 & 4.4 & 1 & 0.07 & 5.8 & & & & & & & & \\
\hline $11 \mathrm{LB} 3 \mathrm{~A}$ & $\begin{array}{l}\text { Reserv } \\
0.05 \\
\end{array}$ & $\begin{array}{c}\text { oir Cre } \\
0.02 \\
\end{array}$ & $\begin{array}{l}\mathrm{e} \\
11.7 \\
\end{array}$ & $<0.1$ & 0.01 & $<0.1$ & 3.7 & 0.74 & 0.05 & 5.2 & 0.55 & 0.05 & 2.5 & 0.4 & & & & \\
\hline
\end{tabular}

Not detected: Ag $<1 \mu \mathrm{g} / \mathrm{L}, \mathrm{As}<1 \mu \mathrm{g} / \mathrm{L}, \mathrm{Be}<0.05 \mu \mathrm{g} / \mathrm{L}, \mathrm{Mo}<2 \mu \mathrm{g} / \mathrm{L}, \mathrm{Sb}<0.3 \mu \mathrm{g} / \mathrm{L}, \mathrm{Se}<1 \mu \mathrm{g} / \mathrm{L}, \mathrm{Th}<0.2 \mu \mathrm{g} / \mathrm{L}, \mathrm{W}<0.5 \mu \mathrm{g} / \mathrm{L}$ 


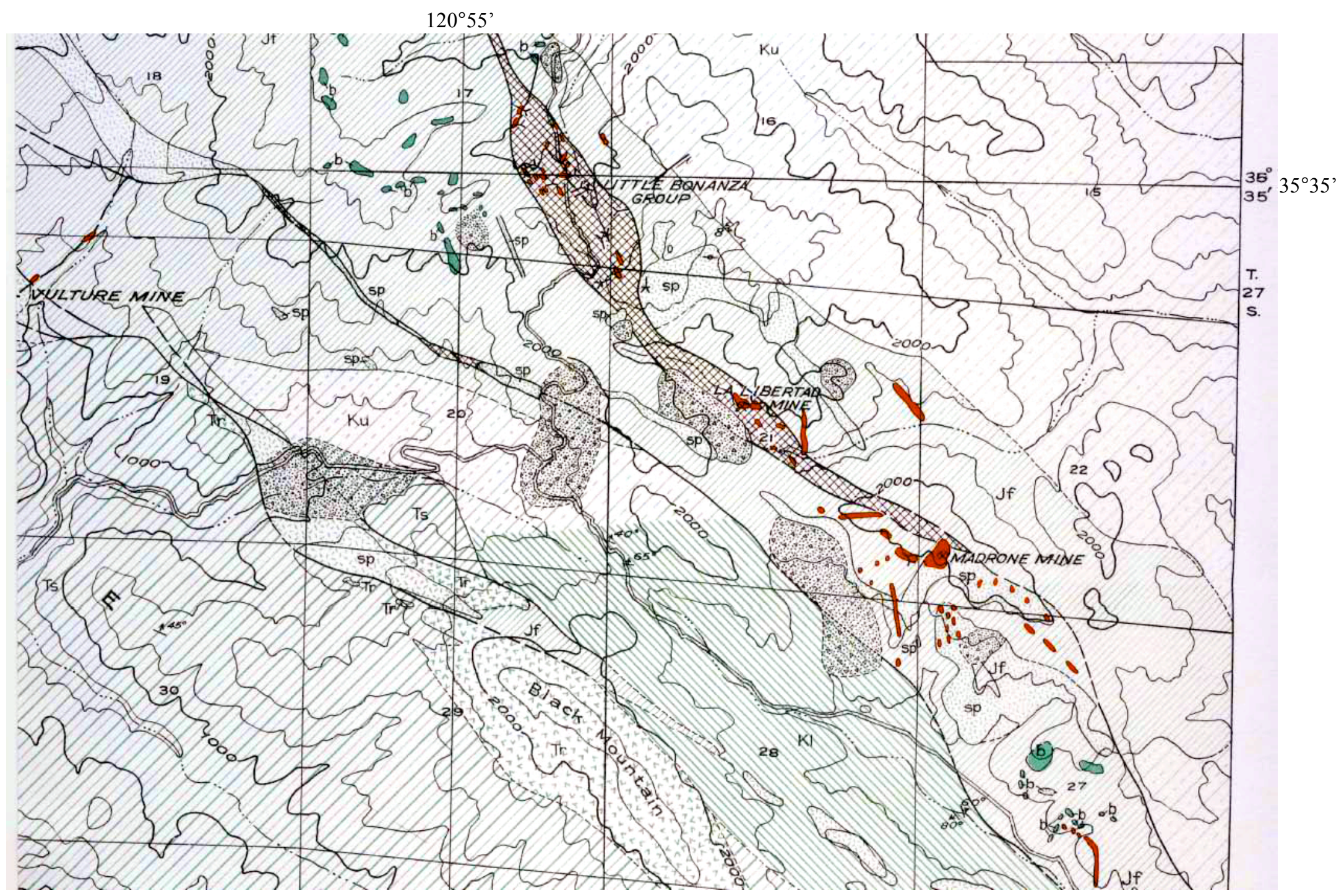

Figure 1. General geology of the Little Bonanza Mine area (Yates and others, 1941). The workings at Little Bonanza explore a zone of fault breccia that trends northwest. The breccia consists of fragments of sandstone, greenstone, serpentine, and chert in a shale matrix. 


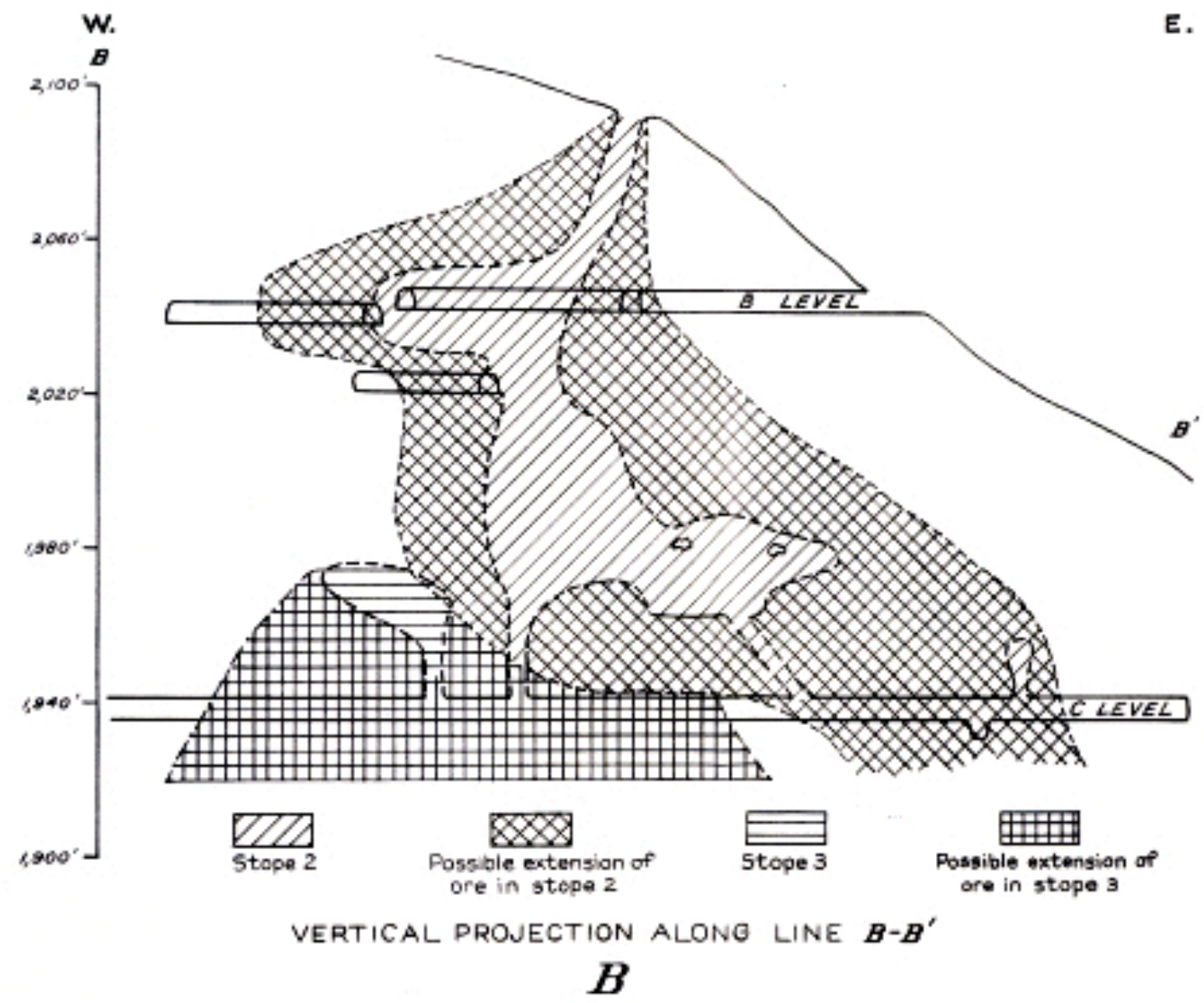

Figure 2. Vertical projection of workings at the Little Bonanza Mine (Yates and others, 1941). 


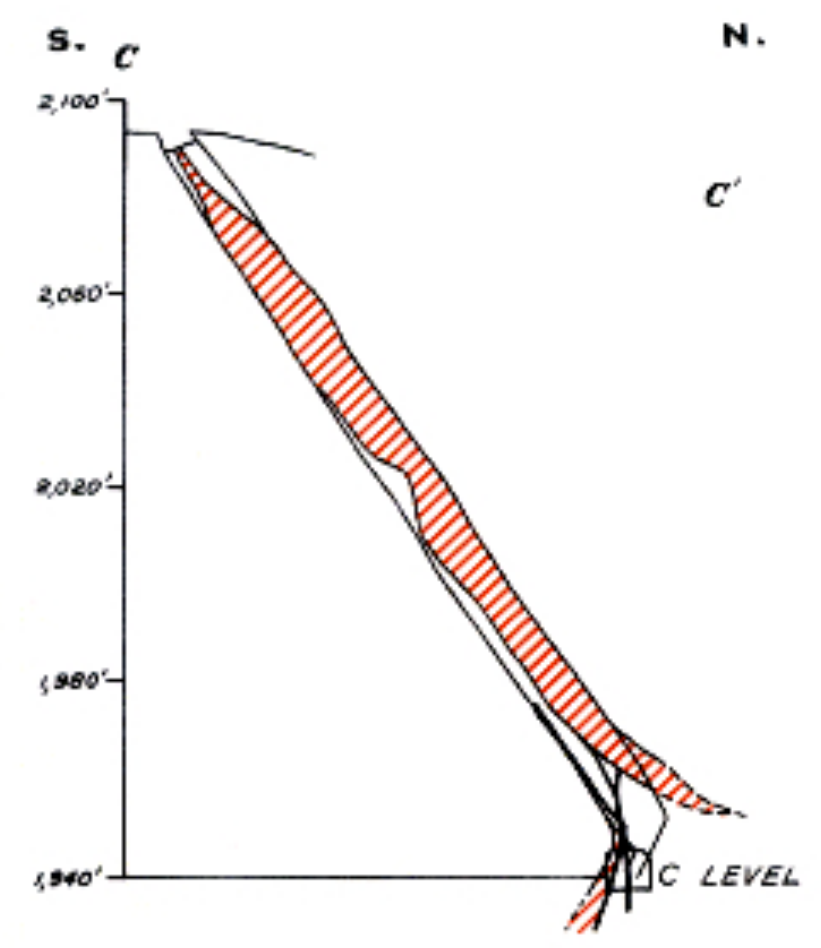
SKETCH CROSS SECTION ALONG LINE $C-C^{\prime}$
SHOWING RELATIONS OF ORE SHOOTS $C$

Figure 3. Cross-section of ore shoots at the Little Bonanza Mine (Yates and others, 1941). 

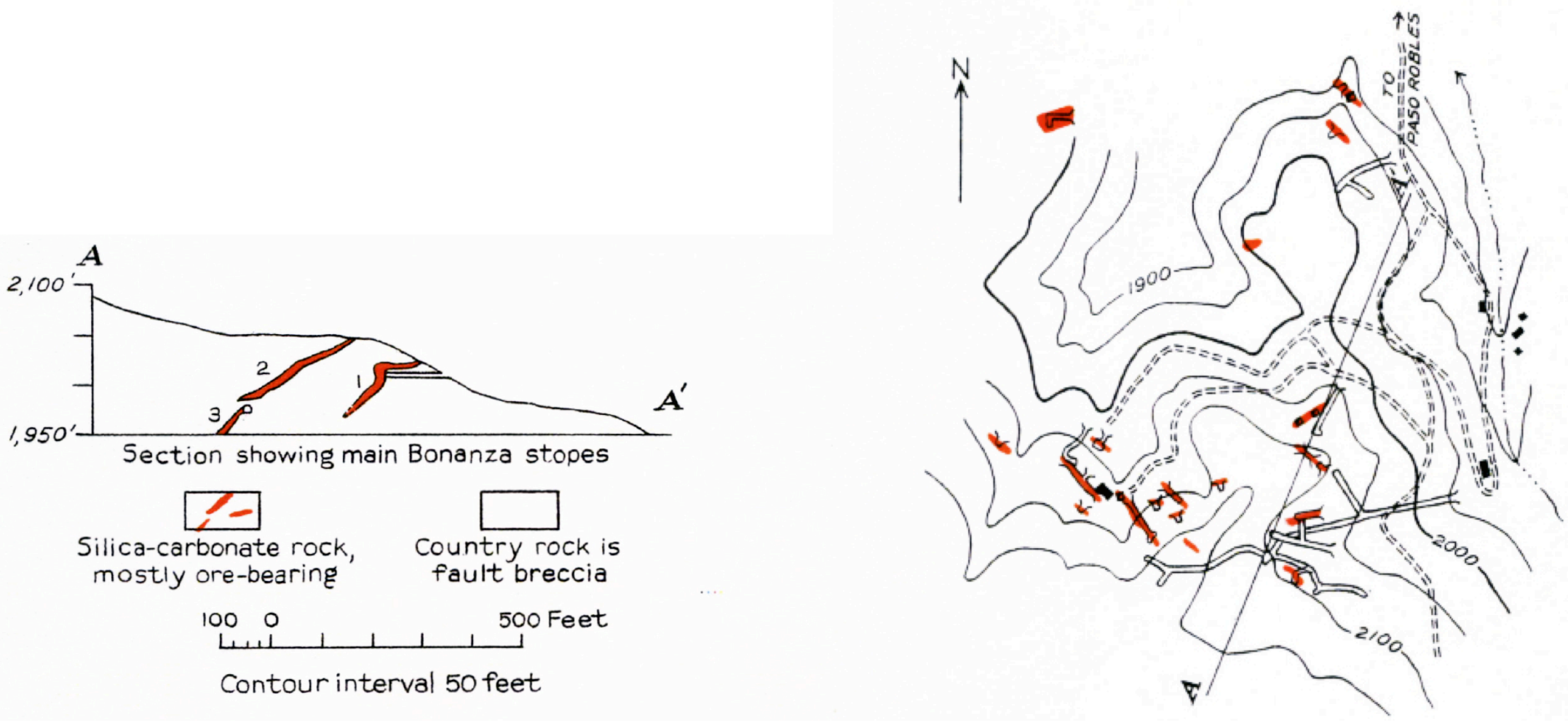

Figure 4. Mine workings at the Little Bonanza Mine, with a cross section showing alteration and mercury ore zones (Yates and others, 1941). 


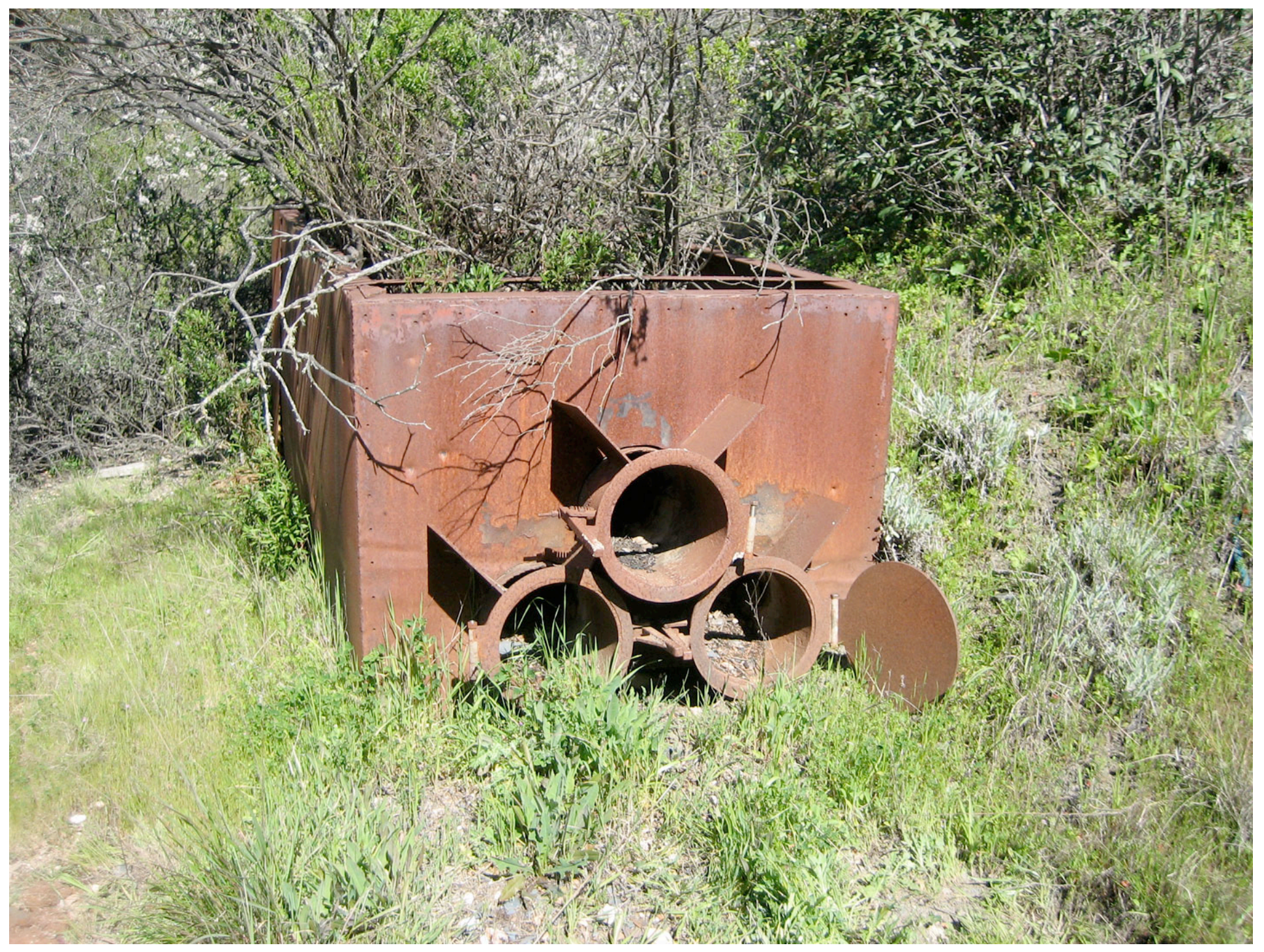

Figure 5. Three-pipe retort at the Little Bonanza Mine that was used to process $\mathrm{Hg}$ ores. 


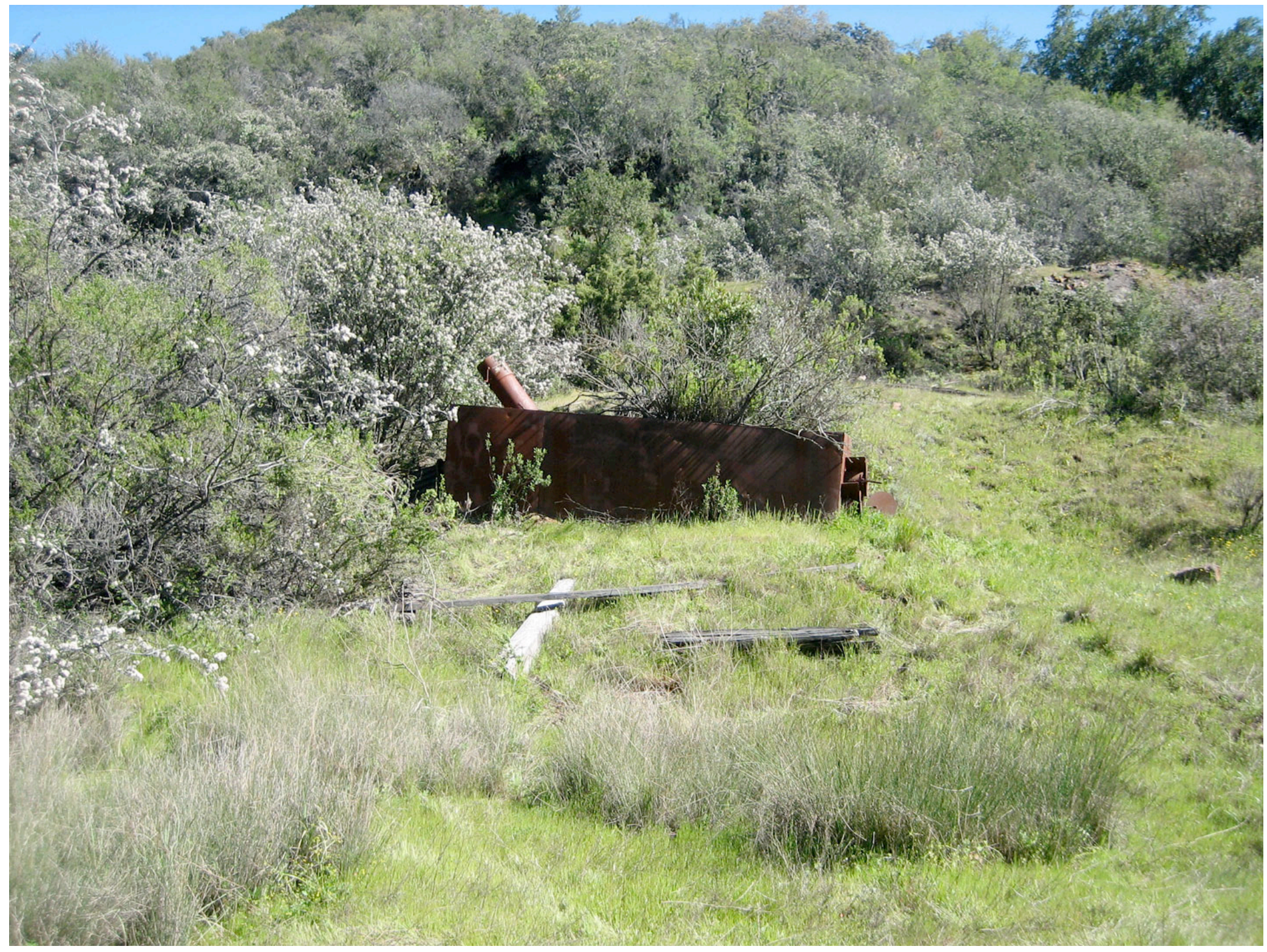

Figure 6. Mine processing area at the Little Bonanza Mine, showing remains of a three-pipe retort. 


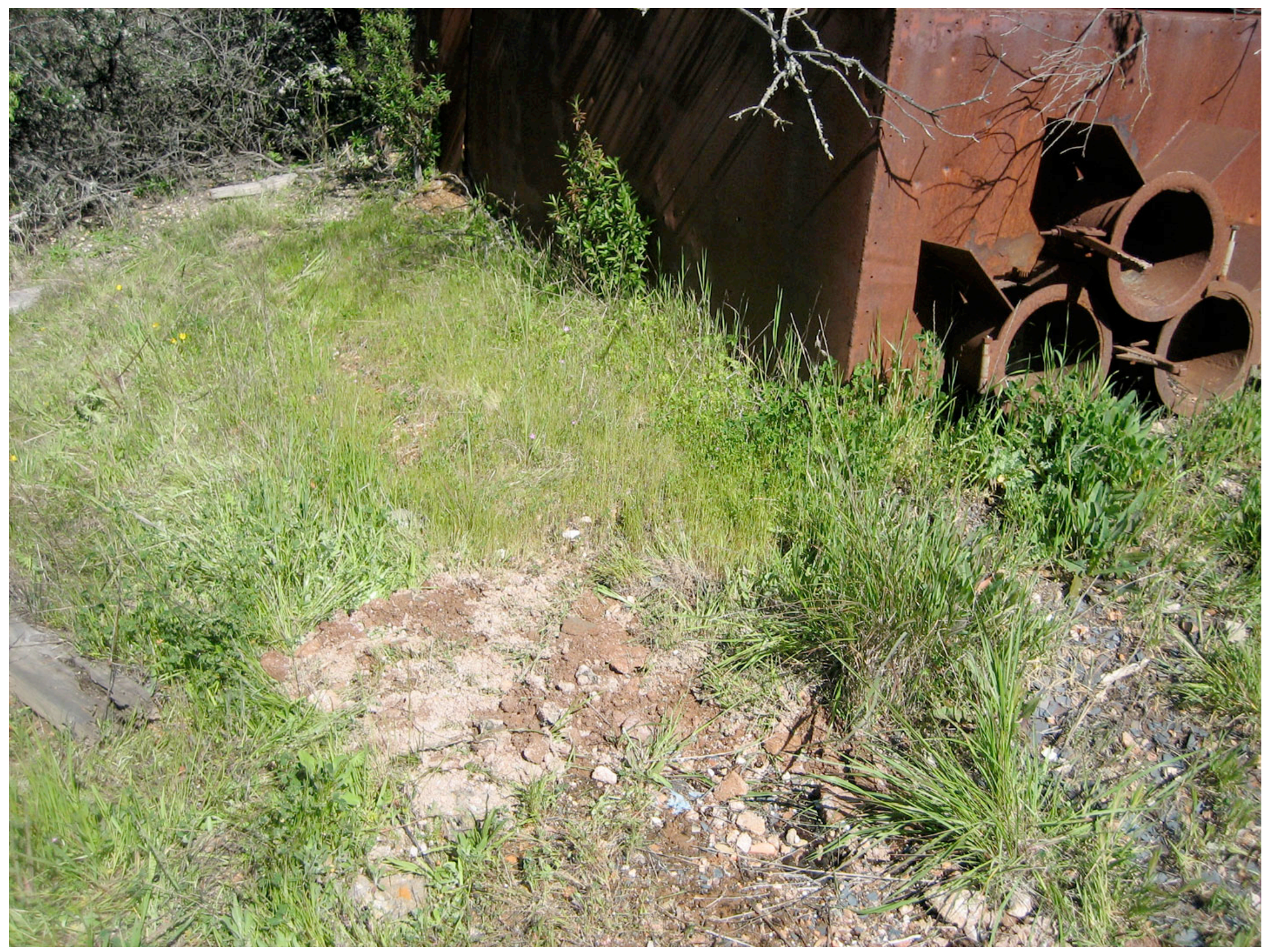

Figure 7. Calcines (mine tailings) adjacent to retort at the Little Bonanza Mine. 


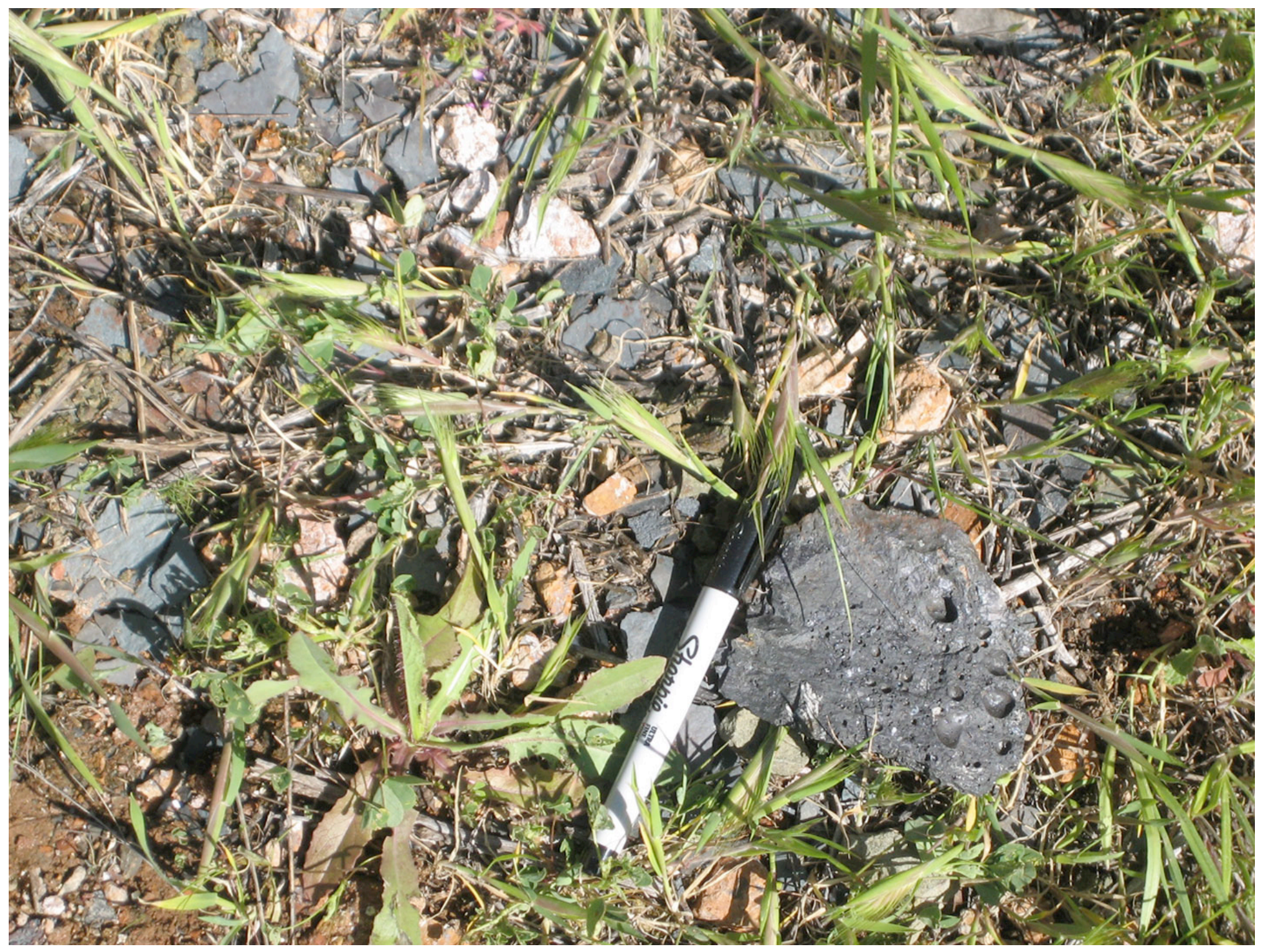

Figure 8. Sulfides that formed in three-pipe retort at the Little Bonanza Mine. 


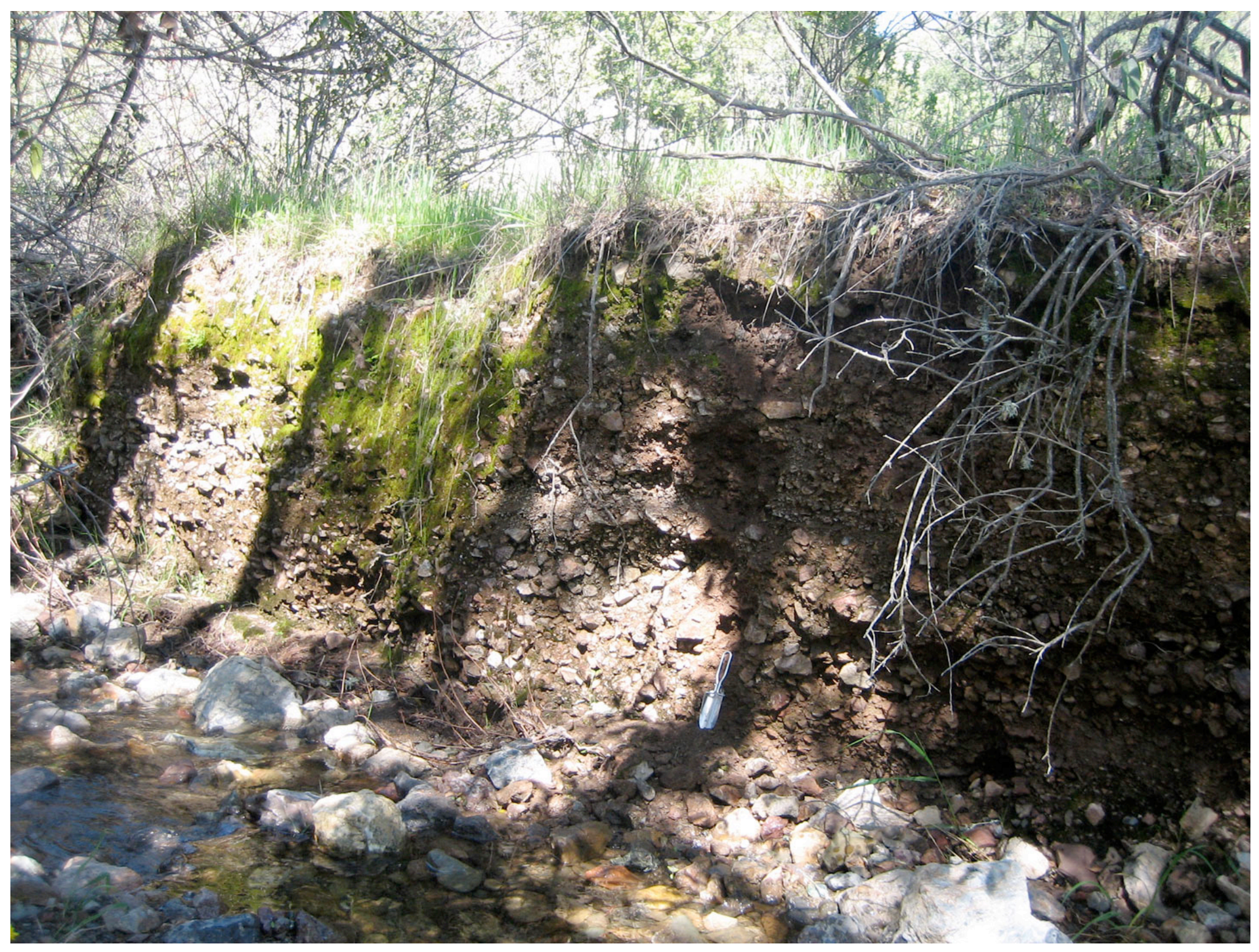

Figure 9. Calcines (mine tailings) at the Little Bonanza Mine exposed along bank of WF Las Tablas Creek. 


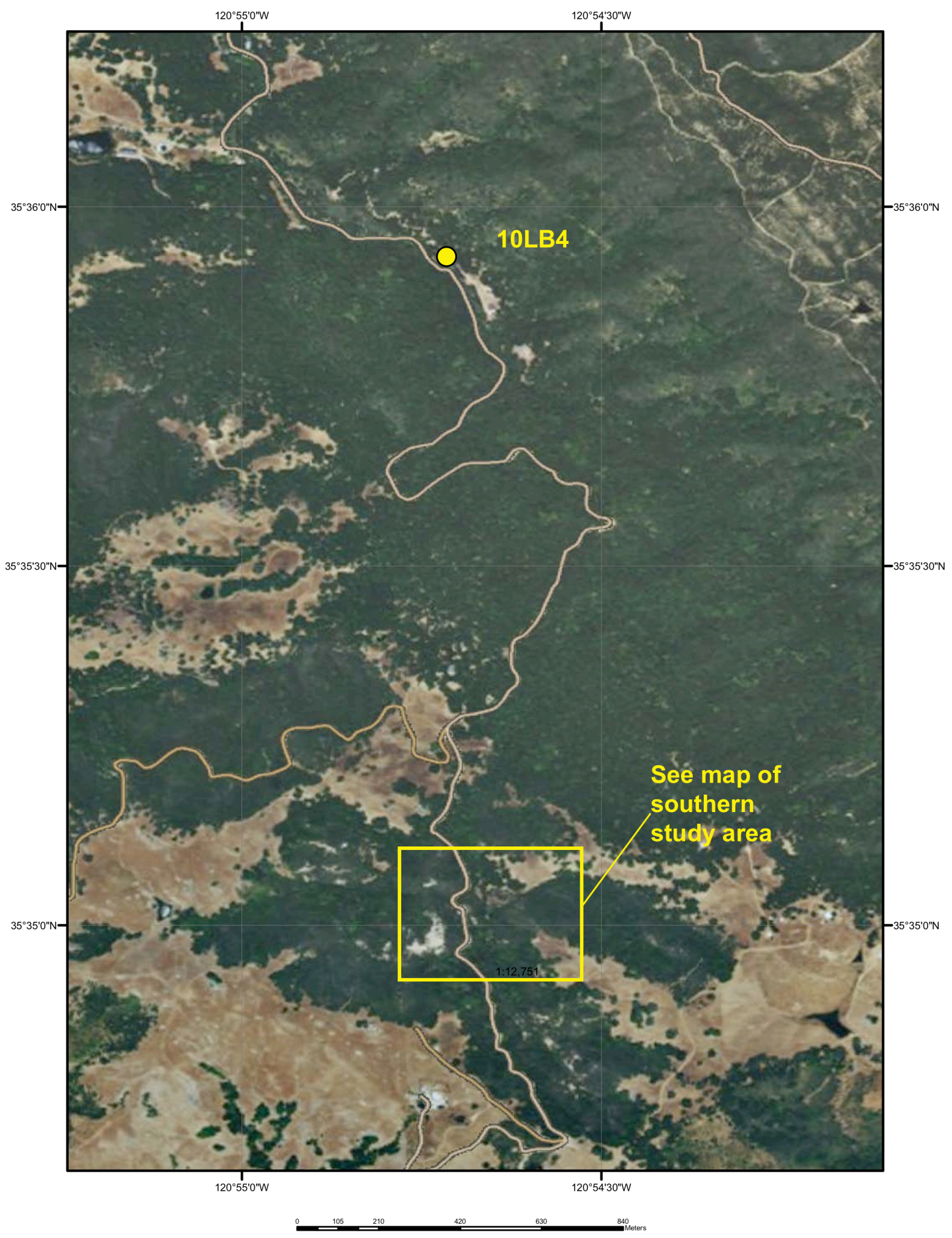

Figure 10. Little Bonanza Mine area, showing locations of all sample sites (Google Earth). Area in yellow box is shown in detail in figure 11. 

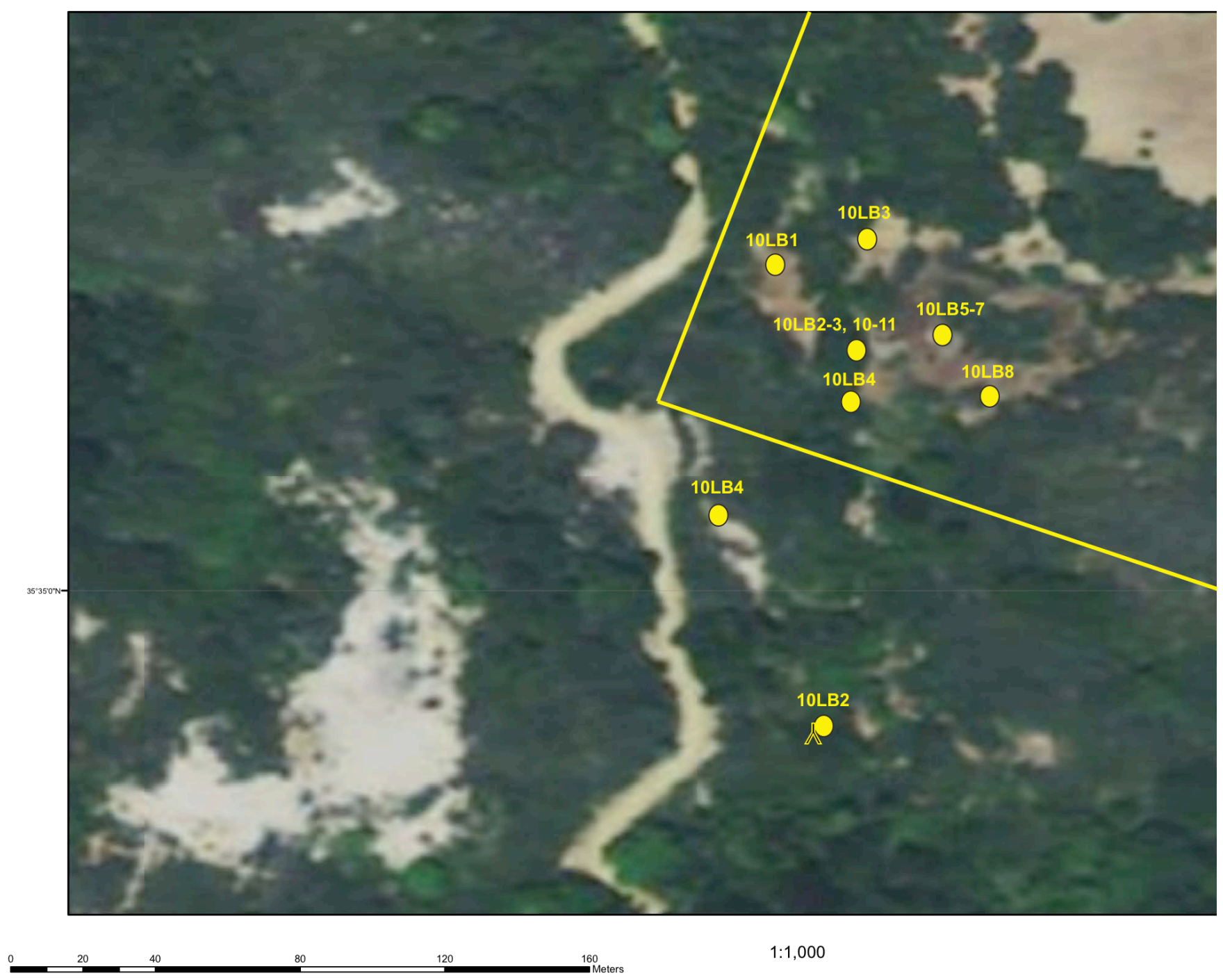

$1: 1,000$

Figure 11. Closeup of figure 10, showing locations of sample sites in mine area (Google Earth). Yellow box delineates land managed by BLM. 


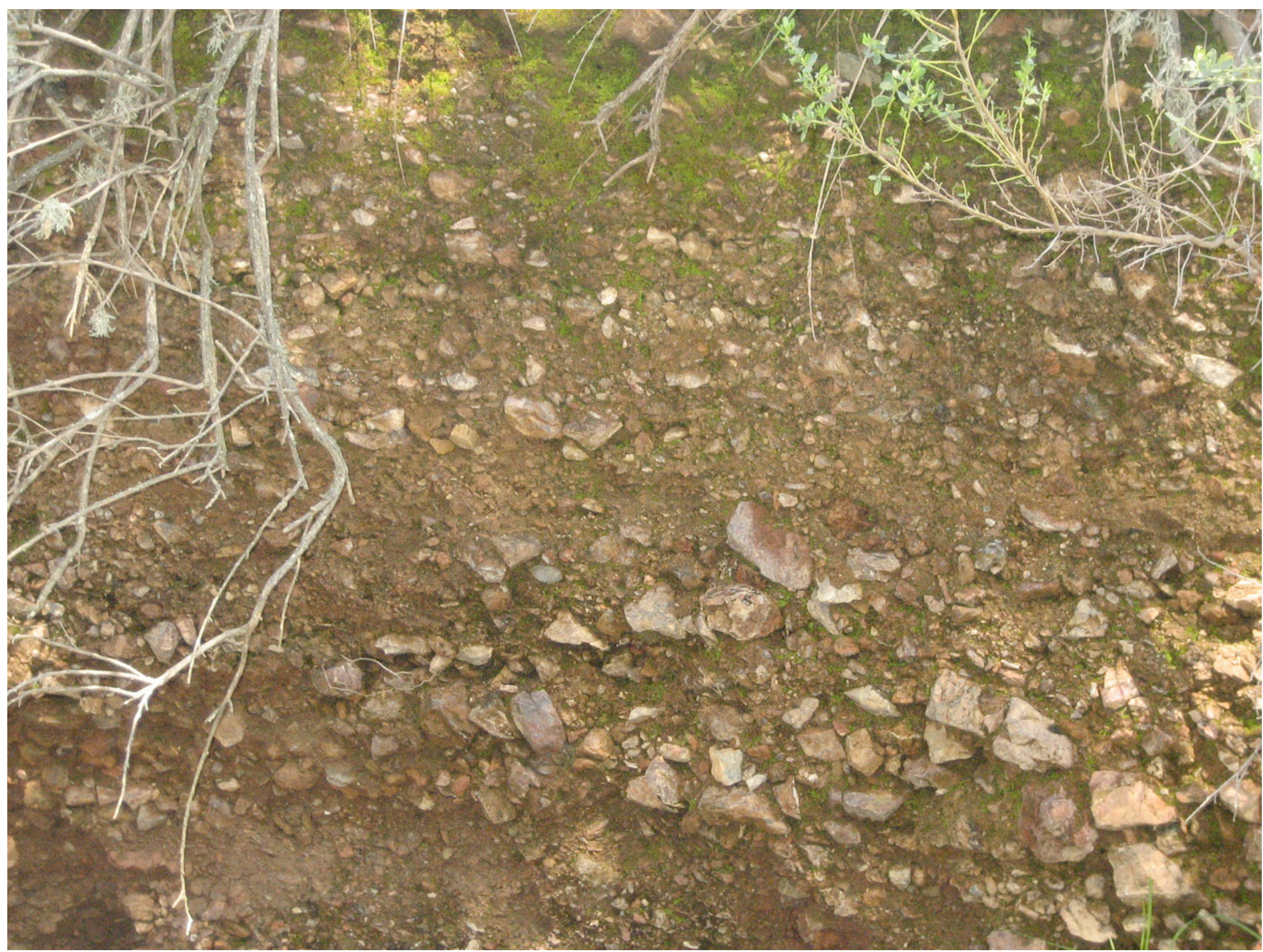

Figure 12. Coarse-grained calcines (mine tailings) exposed in bank of WF Las Tablas Creek at the Little Bonanza Mine. 


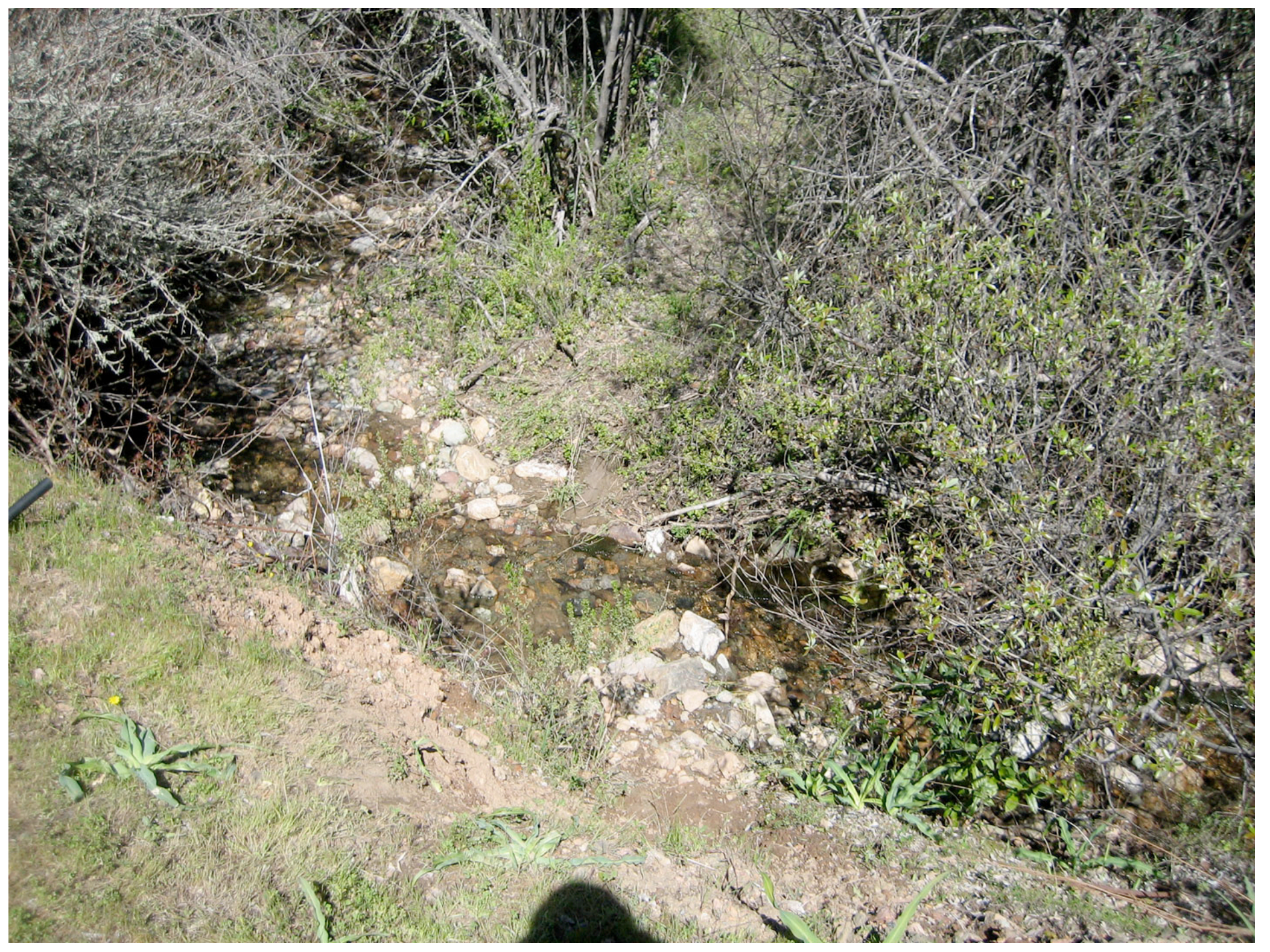

Figure 13. Sample site 10LB1 in WF Las Tablas Creek at the Little Bonanza Mine. 


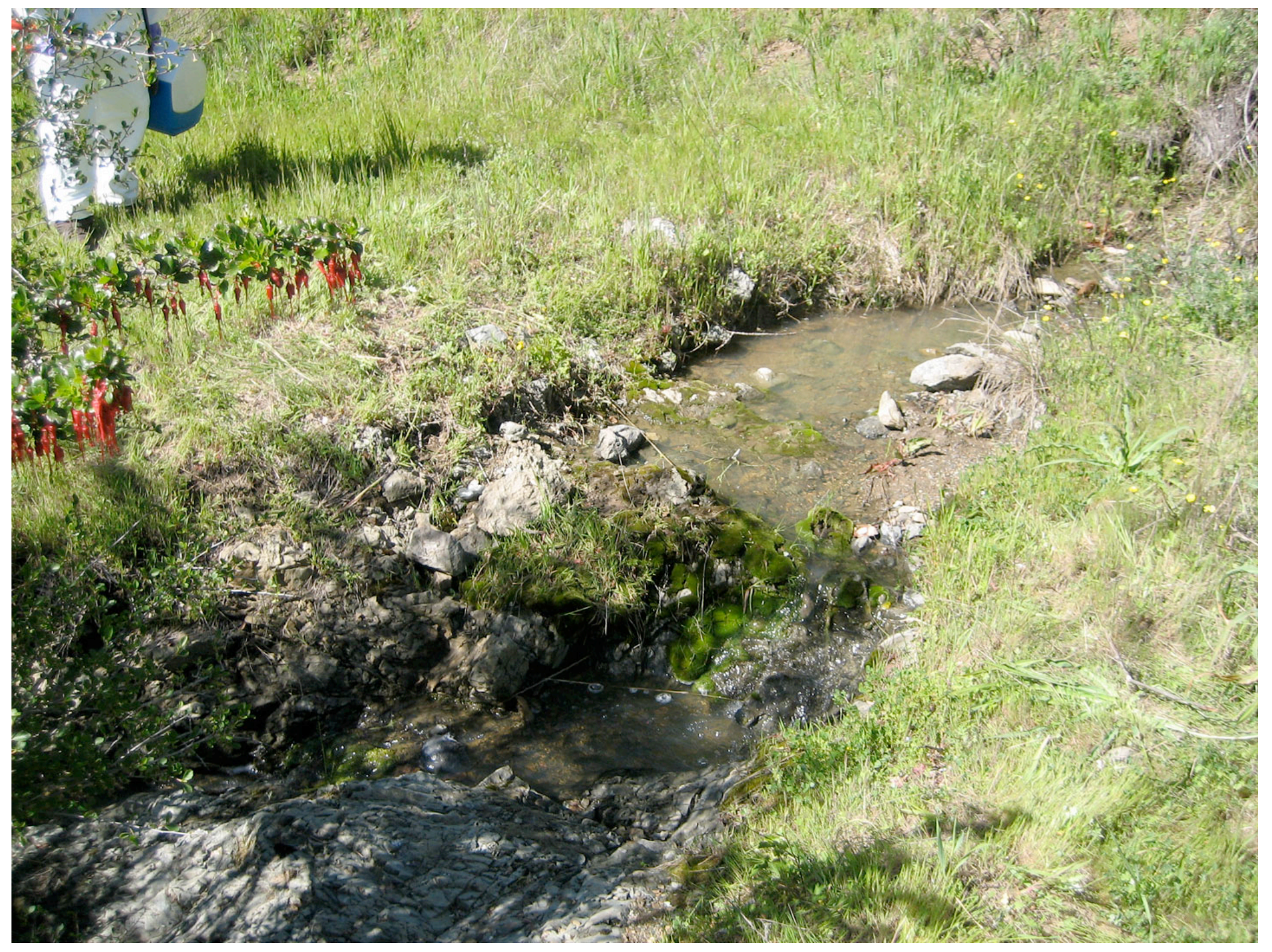

Figure 14. Sample site 10LB3 in creek that extends into area of dam, now failed, at the Little Bonanza Mine. 


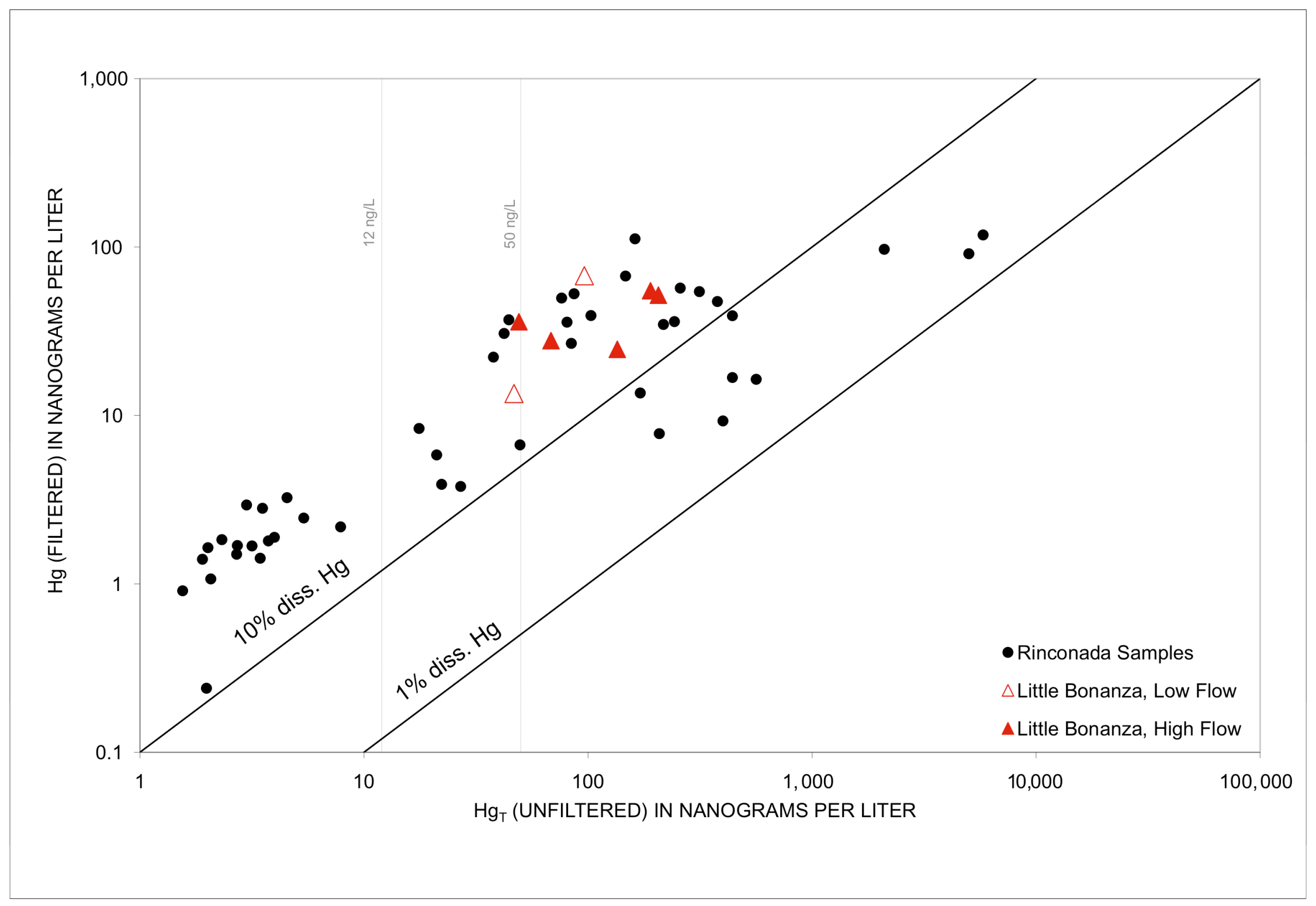

Figure 15. $\mathrm{Hg}$ concentration in unfiltered versus filtered samples from the Rinconada and Little Bonanza Mines. 


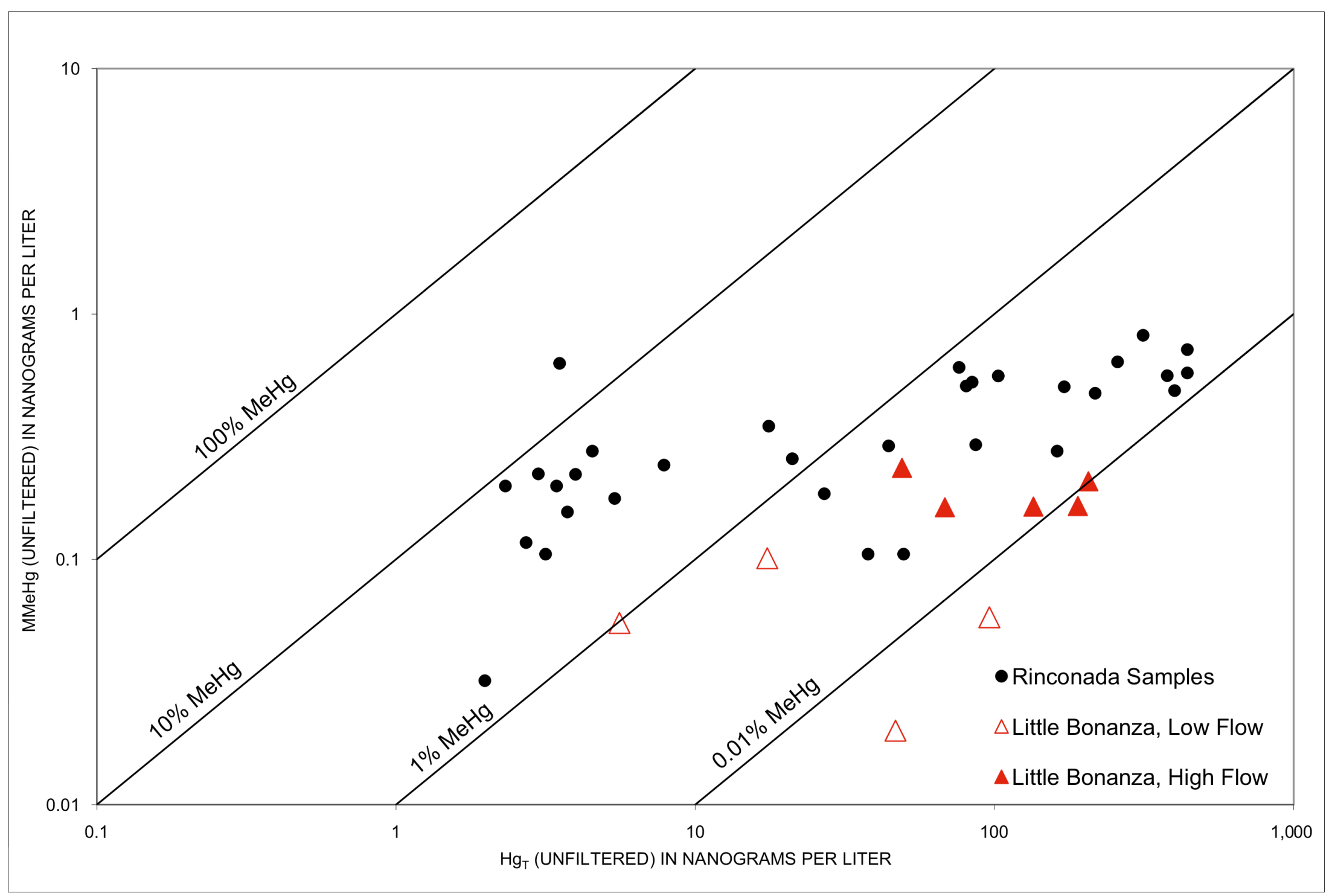

Figure 16. Hg versus MMeHg concentrations in unfiltered water samples from the Rinconada and Little Bonanza Mines. 


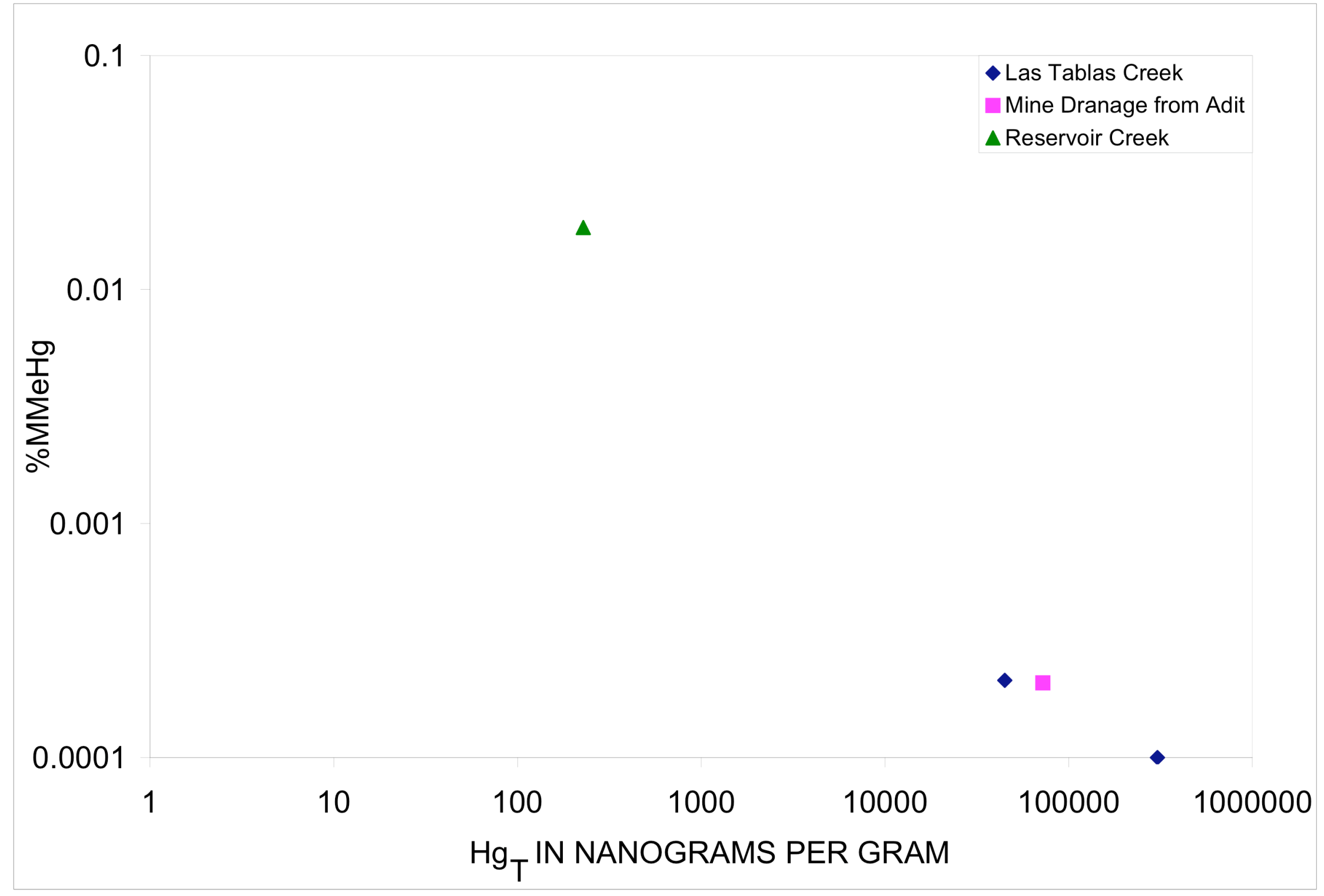

Figure 17. $\mathrm{Hg}$ concentration versus \%MMeHg in sediment samples from the Little Bonanza Mine. 


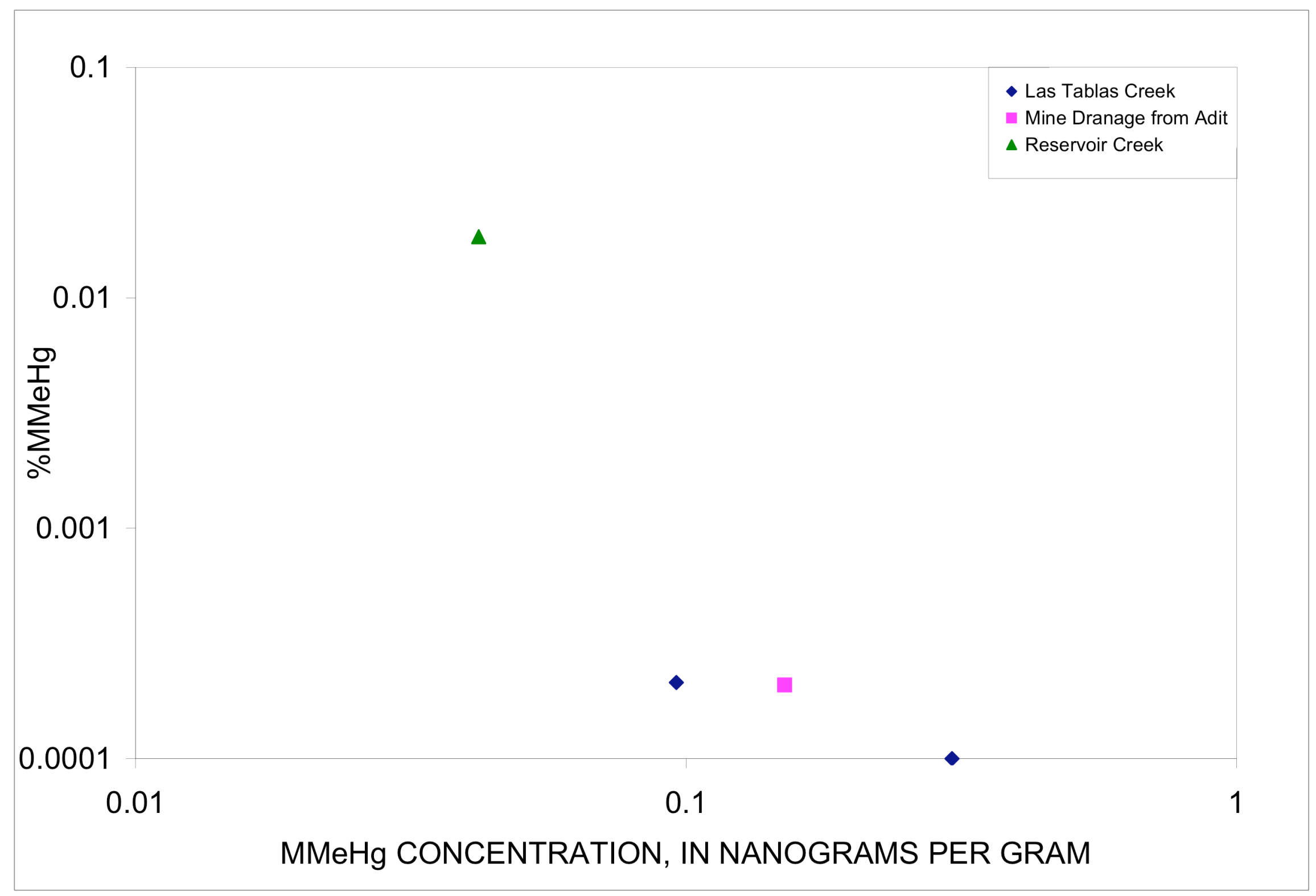

Figure 18. MMeHg concentration versus \%MMeHg in sediment samples from the Little Bonanza Mine. 


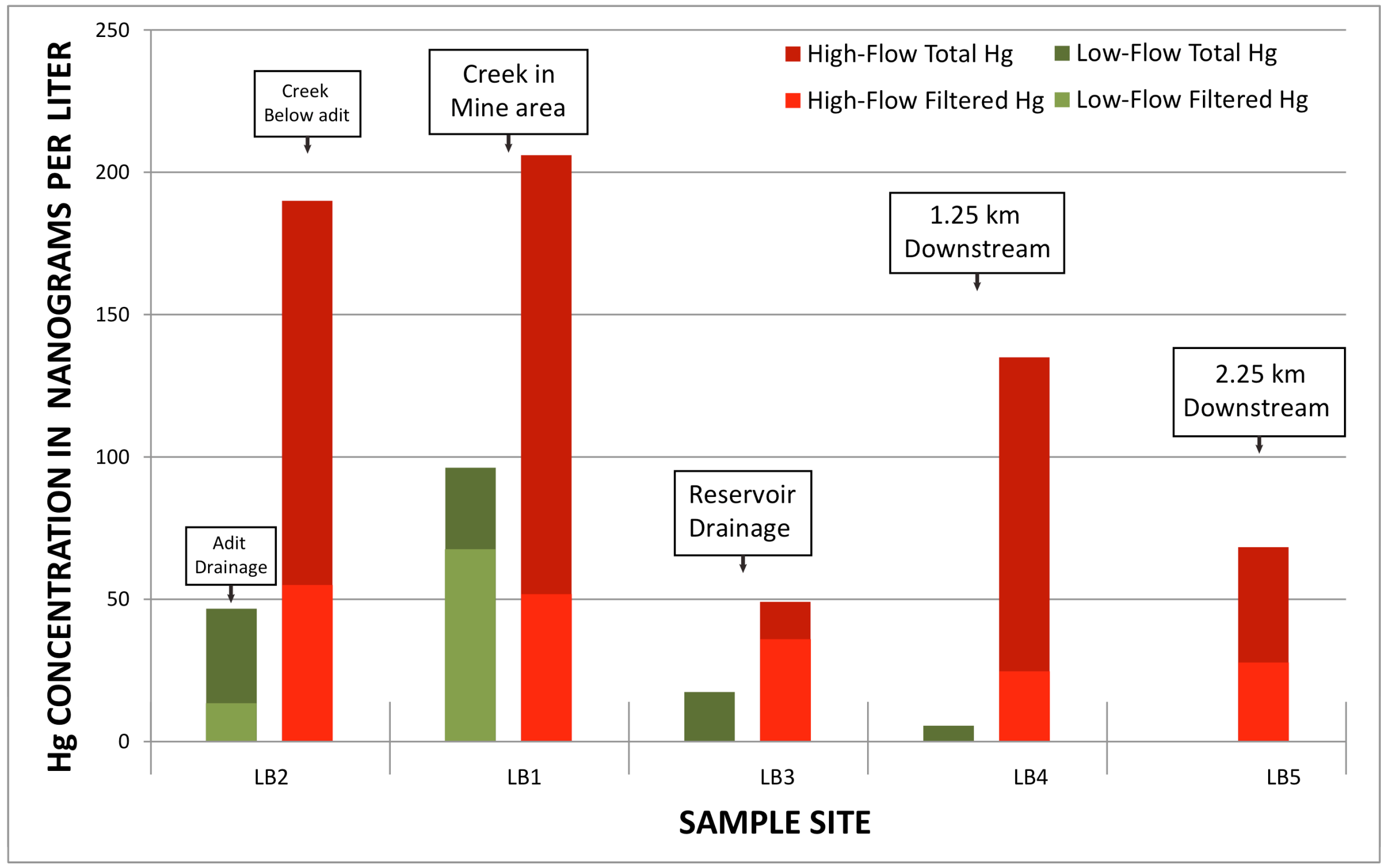

Figure 19. Comparison of $\mathrm{Hg}_{\mathrm{T}}$ and dissolved $\mathrm{Hg}$ concentrations in waters sampled at the Little Bonanza Mine, beginning with the most upstream sample site, LB2, at the adit, and moving downstream to sample sites LB1, LB3, LB4 and LB5, respectively. 